\title{
LA POESÍA Y SUS CONSTITUTIVOS ESENCIALES SEGÚN FEIJOO
}

\section{Poetry and its Essential Constituents According to Feijoo}

\author{
Rodrigo OLAY VALDÉS ${ }^{1}$ \\ Universidad de Oviedo \\ olayrodrigo@uniovi.es
}

Fecha de recepción: 19/10/2014

Fecha de aceptación definitiva: 02/10/2015

RESUMEN: A lo largo de su obra ensayística, Feijoo hace numerosas alusiones a lo que él cree que debe ser la poesía. Así, defiende que sus constitutivos esenciales han de ser "entusiasmo» (intensidad) y "versificación» (ritmo). Además, observa que la no ficción debe ser considerada otro constitutivo igualmente relevante, pues facilita la capacidad docente y la utilidad de la poesía. A causa de su defensa de la no ficción como vía para enfatizar el docere, Feijoo llegó a preferir la Farsalia de Lucano por encima de la Eneida de Virgilio. Asimismo, Feijoo mantuvo que la naturalidad debía ser el último requisito imprescindible de la poesía, lo que se sustanció en su caso en una dura crítica de los excesos barrocos y en la defensa de los modelos literarios y las estrategias de composición clásicos que pronto abanderaría el Neoclasicismo.

Palabras clave: Feijoo; poesía; constitutivos esenciales; preceptiva literaria.

SUMMARY: Throughout his essays, Feijoo makes numerous references to his own definition of poetry. He argues that the essential constituents of poetry must be "enthusiasm» (intensity) and "versification» (rhythm). Feijoo considers that non-fiction

1. Esta investigación se ha desarrollado gracias a un contrato predoctoral FPW financiado por el Ministerio de Educación, Cultura y Deporte. Además, el presente estudio se enmarca en el proyecto de investigación Sujeto e institución literaria en la Edad Moderna, FF12014-54367-C2-1-R. 
should be regarded as another relevant constitutive of poetry, because non-fiction facilitates the teaching ability and usefulness of poetry. On account of his defense of non-fiction as a way to emphasize the docere, Feijoo came to prefer Lucan's Pharsalia above Virgil's Aeneid. Finally, Feijoo also maintained that naturalness was the last requisite of poetry, so he criticized the excesses of Baroque and he defended the literary models and the classical composition strategies that Neoclassicism would soon recover.

Key words: Feijoo; Poetry; Essential constituents; Literary precepts.

Benito Jerónimo Feijoo (1676-1764) ofrece en sus catorce tomos de Teatro crítico universal (1726-1740) y Cartas eruditas y curiosas (1742-1760) numerosas apreciaciones sobre poética que pueden considerarse uno de los primeros corpus de índole preceptiva de su siglo. Fragmentariamente -como ha explicado, entre otros, Russell P. Sebold- ${ }^{2}$, Feijoo disemina, al paso de los variados temas tratados en cartas y discursos, diferentes apreciaciones acerca de la poesía de su tiempo, las grandes obras de los siglos pasados y lo que entiende que debe ser considerado y definido como poesía. Sus ensayos proponen una vuelta a los referentes poéticos de los siglos áureos de la literatura latina y a lo que, con matices, pronto será el canon dieciochesco de los Siglos de Oro españoles ${ }^{3}$.

Sin embargo, este conjunto de textos de tema poético no llega en el caso de Feijoo a constituir una poética exhaustiva ni completa. De hecho, las reflexiones feijonianas sobre poesía, dejando al margen los pocos ensayos específicamente literarios que escribió, se encuentran disgregadas entre contenidos tan dispersos como la teología escolástica, a la que a fin de cuentas se dedicó profesionalmente toda la vida ("Mérito y fortuna de Aristóteles», TCU, IV, VIII; 1730), llamativas minucias biológicas ("Sobre el tránsito de las arañas de un tejado a otro", CEC, I, XIX; 1742), la geología («Sobre la incombustibilidad del amianto», CEC, II, XII; 1745), las costumbres ("Sobre los duelos o desafíos», CEC, IV, III; 1753) o las innovaciones pedagógicas («Sobre la invención del arte que enseña a hablar a los mudos», CEC, IV, VII; 1753) y ginecológicas ("Uso más honesto del Arte obstetricia o de partear», CEC, II, XVII; 1745), entre docenas de ejemplos de diferente pelaje.

2. Sebold, Russell P. Lírica y poética en España, 1536-1870. 1. ${ }^{a}$ ed., Madrid: Cátedra, 2003.

3. Olay VAldÉs, Rodrigo. "Reconstrucción del canon poético en el ensayo de Feijoo». Cuadernos de Estudio del Siglo XVIII, 2013, 23, pp. 151-194.

4. Siempre que citamos un fragmento feijoniano, indicamos su título abreviado (TCU para Teatro crítico universal; CEC para Cartas eruditas y curiosas; IA para Ilustración apologética; y JR para Justa repulsa de inicuas acusaciones), y después el volumen, el número de carta o discurso, el parágrafo, si lo hubiera, indicado por el signo §, el número de párrafo, y, tras punto y coma, el año de la primera edición del tomo referido. Citamos por la edición de las obras completas de Feijoo impresas por Blas Román en Madrid en 1781. Por último, modernizamos en cada caso ortografía y puntuación. 
Esta asombrosa variedad temática de Feijoo ha propiciado dos fenómenos en particular: primeramente, ha hecho que la dimensión más puramente literaria de su obra no fuese observada con la profundidad debida; en segundo lugar, ha motivado que los estudios feijonianos se escorasen hacia espectros del saber muy alejados de la filología, tales como la medicina, la biología, la antropología o la música. Pedro Álvarez de Miranda apuntaba con acierto no hace mucho que la influencia del gran clásico de Gregorio Marañón, Las ideas biológicas del Padre Feijoo (1934), había sido a este respecto decisiva, pues "propició la aparición de otros estudios en cuyos títulos se sustituía la palabra biológicas por la que convenía a cada caso" ${ }^{5}$. No obstante, sería injusto achacar a Marañón cualquier tipo de deformación en el devenir del estudio de la obra de Feijoo, pues, pese al título de su obra, Marañón efectúa en su libro un verdadero análisis de conjunto de la figura y la labor de Feijoo, y no olvida atender, por ejemplo, a su estilo literario, sus lecturas o incluso su labor poética, entre otros muchos asuntos ${ }^{6}$. En resumen, sin buscar emprender ningún tipo de operación desnaturalizadora que niegue alguna de las múltiples caras de la obra de Feijoo, creemos que es importante que la filología recupere el espacio que de suyo le pertenece y que, de tal forma, Feijoo empiece a ser principalmente considerado de una vez por todas como lo que es ante todo: un escritor, un literato. De esta manera, se impone examinar literariamente su obra y recuperar, como aquí pretendemos, sus ideas sobre literatura, y, en este caso, sobre poesía.

Con vistas a analizar y reconstruir las ideas poéticas de Feijoo, hemos procurado localizar en su obra aquellos tópicos que constituyen otros tantos núcleos de su pensamiento y que jalonan su construcción teórica a lo largo del tiempo, ya que no debemos perder de vista que Feijoo comienza a hablar de poesía en el tomo primero del Teatro crítico universal (1726), en cuyo decimosexto discurso Feijoo ataca con violencia lo que considera determinados excesos de la poesía barroca, y seguirá refiriéndose a la poesía en el quinto y último tomo de las Cartas eruditas y curiosas (1760), en cuya vigésimo primera carta vuelve sobre el conocido "Pleito de Lucano» y al hilo de la diatriba define qué entiende por poesía.

Por su parte, proponer un listado de discursos y cartas feijonianos dedicados a la preceptiva poética es menester quizá no excesivamente útil, condenado además de partida a la arbitrariedad. A fin de cuentas, son pocos los escritos feijonianos dedicados exclusiva o incluso mayoritariamente al tratamiento de temas poéticos; más bien, como hemos dicho, trufa sus trabajos de alusiones, sembradas aquí y allá, del mismo modo en que convoca versos, generalmente de los poetas clásicos latinos, al paso de los variopintos temas que va tratando.

5. Álvarez de Miranda, Pedro. "Perfil literario del Padre Feijoo». En URZAinqui, Inmaculada (ed.). Feijoo, hoy (Semana Marañón 2000). 1. ${ }^{a}$ ed., Oviedo: Fundación Gregorio Marañón-Instituto Feijoo de Estudios del siglo XVIII, 2003, pp. 119-129; la cita en p. 119.

6. Citamos por la segunda edición: MARAÑón, Gregorio. Las ideas biológicas del Padre Feijoo. 2. ${ }^{\text {e }}$ ed. [1. ${ }^{\text {e }}$ ed. 1934], Madrid: Espasa Calpe, 1941. 
En cualquier caso, podríamos atrever la siguiente nómina de discursos donde se abordan significativamente los intereses y opiniones poéticos de Feijoo. Del Teatro crítico universal, en el tomo primero (1726), el "Discurso VII: Desagravio de la profesión literaria», el "Discurso XIV: Música de los templos» y el "Discurso XV: Paralelo de las lenguas castellana y francesa"; en el tomo segundo (1728), el «Discurso VIII: Sabiduría aparente» y el "Discurso XV: Mapa intelectual y cotejo de naciones»; en el tomo cuarto (1730), el «Discurso VIII: Reflexiones sobre la historia", el "Discurso XII: Resurrección de las artes y apología de los antiguos», el "Discurso XIII: Glorias de España (primera parte)» y el «Discurso XIV: Glorias de España (segunda parte)»; en el tomo quinto (1733), el "Discurso VIII: Divorcio de la historia y la fábula»; en el tomo sexto (1734), el "Discurso II: Apología de algunos personajes famosos de la historia", el "Discurso XI: Razón del gusto» y el «Discurso XII: El no sé qué»; y, finalmente, en el tomo séptimo (1736), el «Discurso X: Verdadera y falsa urbanidad».

Por su lado, de las Cartas eruditas y curiosas, en el tomo primero (1742), la "Carta XXXIII: Defiéndese la introducción de algunas voces peregrinas o nuevas en el idioma castellano" y la "Carta XLII: Origen de la fábula en la historia»; en el tomo segundo (1745), la "Carta VI: La elocuencia es naturaleza y no arte", la "Carta VII: Dichos y hechos graciosos de la Menagiana (parte primera)", la "Carta VIII: Dichos y hechos graciosos de la Menagiana (parte segunda)" y la "Carta XVIII: De la crítica»; en el tomo tercero (1750), la "Carta V: Respuesta a dos objeciones»; en el tomo cuarto (1753), la "Carta XII: Advertencia a los autores de libros y a los impugnadores o censores de ellos» y la "Carta XIII: Si en la prenda de ingenio exceden unas naciones a otras»; y, ya por último, en el tomo quinto (1760), la "Carta VIII: El estudio no da entendimiento", la "Carta XXI: Reforma el autor una cita que hizo en el tomo IV del Teatro crítico y después tuvo motivo para dudar de su legalidad; con cuya ocasión entra en la disputa de cual sea el constitutivo esencial de la poesía" y la "Carta XXV: Disuade a un amigo suyo el autor el estudio de la lengua griega y le persuade el de la francesa»"

Pese a este catálogo, no debemos olvidar que las apreciaciones y alusiones poéticas de Feijoo se reparten entre toda su obra ensayística, su epistolario y sus

7. Nuestra lista no coincide exactamente, pese a sus muchas concomitancias, con la que constituye el índice de la única antología monográficamente dedicada a las ideas literarias de Feijoo. Nos referimos a Vila Selma, José (ed.). Feijoo. Ideas literarias. Antología. 1. a ed., Madrid: Publicaciones Españolas, 1963, volumen en que, después de un prólogo dedicado a demostrar que el siglo XVIII no fue tan afrancesado como suele repetirse, pero que apenas nada apunta respecto a las ideas literarias de Feijoo, se recogen las siguientes cartas y discursos: "Desagravio de la profesión literaria", "El estudio no da entendimiento", "Sabiduría aparente», "El no sé qué», "La elocuencia es naturaleza y no arte", "De la crítica", "Origen de la fábula en la historia», "Divorcio de la historia de la fábula", "Apología de algunos personajes famosos de la historia", "Reflexiones sobre la historia", a los que se añaden otros dos discursos sin que alcancemos a comprender por qué, habida cuenta de su discutible contenido literario: "Senectud moral del género humano» y "Honra y provecho de la agricultura». 
propios versos, en los que acostumbra insistir sobre algunos de los más recurrentes temas de su prosa ${ }^{8}$.

\section{LOS CONSTITUTIVOS DE LA POESÍA}

\subsection{Los constitutivos esenciales de la poesía: «entusiasmo» y «versificación»}

Tras una vida dedicada a tratar temas de toda índole y cansado de más de una polémica a causa de sus preferencias literarias, Feijoo decidió a la altura de 1760, en el quinto y último tomo de sus Cartas eruditas y curiosas, ensayar una definición personal de la poesía que recogiera sus ideas al respecto enunciadas a lo largo de más de treinta años. Puesto ante la tesitura de establecer qué es la poesía, Feijoo considera que un texto para ser poético debe reunir dos ingredientes, a los que él llamó «entusiasmo» y «versificación» (CE, V, XXIII; 1760). Define el primero, en la línea platónica, como «una imaginación inflamada con aquella especie de fuego a quien los mismos poetas dieron nombre de furor divino. Y de parte del efecto consiste en un lenguaje elevado, compuesto de locuciones más enérgicas, de figuras más brillantes, de imágenes ya más grandiosas, ya más vivas» (CEC, V, 19, 16; 1760); el segundo, como "música cuya modulación se representa en la artificiosa colocación de palabras y sílabas» (CEC, V, 19, 16; 1760). Por «entusiasmo», entonces, debemos entender una mixtura entre 'emoción', 'inspiración' y 'elaboración retórica' (Feijoo anota que también es el entusiasmo un componente esencial de la oratoria); por "versificación", lo que hoy llamaríamos 'musicalidad' o 'ritmo'.

Que Feijoo entienda que el «entusiasmo» es trascendental para la poesía coincide con una afirmación suya, hecha ya en 1726, en el primer tomo de su Teatro crítico universal, en la que la concibe como un "rapto de la mente». Él mismo nos había dicho que «quien quiere que los poetas sean muy cuerdos quiere que no haya poetas. El furor es la alma de la poesía. El rapto de la mente es el vuelo de la pluma: Impetus ille sacer, qui vatum pectora nutrit, dijo Ovidio" (TCU, I, XV, § VI, 32; 1726). Esta definición báquica del poeta se corresponde paladinamente con el ideal de estilo que Feijoo defiende, esto es, el de Lucano. Para Feijoo, Lucano es «siempre despierto, vivo, ardiente, armonioso, enérgico, sublime, por todo el discurso de su poema [la Farsalia] se mantiene en aquella elevación donde le vemos colocarse al primer rapto del numen" (TCU, IV, XIV, § XV, 43; 1730). Ahí, como vemos, radica el quid de su concepción poética; por eso no debe extrañarnos que

8. Así, por ejemplo, Feijoo escribe un romance dedicado a la «Explicación del no sé qué de la belleza" o unas décimas a desmontar "Un falso milagro atribuido a San Francisco de Paula" Ya fue esto advertido por Álvaro Ruiz de la Peña en RuIz DE la PEÑa, Álvaro. «Notas en torno al talante civil de Feijoo». En Álvarez Barrientos, Joaquín y Checa Beltrán, José (eds.). El siglo que llaman ilustrado. Homenaje a Francisco Aguilar Piñal. 1. ${ }^{a}$ ed., Madrid: CSIC, 1996, pp. 765-771; el dato en p. 769.

9. Pónticas, IV , 4, v. 25: «El ímpetu sagrado que nutre el pecho de los poetas». Las traducciones y los subrayados serán siempre nuestros a menos que se indique lo contrario. 
en ocasiones le reproche a Virgilio la ausencia de ímpetu que en él nota, ya que no ve en el autor de la Eneida ese aludido furor, y dice del de Mantua que utiliza una dicción tan augusta y sosegada, tan senatorial, que se acerca más al tono ensayístico que al poético, habida cuenta de que este último demanda más energía y, en definitiva, "entusiasmo» (TCU, IV, XIV, § XIV, 41; 1730).

En segundo lugar, Feijoo entiende la versificación, la musicalidad, como esencial en el poema, para lo cual no duda en aducir los testimonios de dos de sus poetas predilectos, Horacio y Virgilio:

La poesía no puede prescindir de la versificación; mas como el entusiasmo también es algo admisible en la oratoria, en la esencia de la poesía al entusiasmo debe agregarse como parcial constitutivo de ella la versificación. [...] [Los poetas] frecuentemente dan el nombre de canto y música a la poesía. Virgilio: Sicelides Musae paulo moiora canamus [Bucólicas, IV, v. 1: Musas de Sicilia, elevemos un poco nuestros cantos]. El mismo: Arma, virumque cano [Eneida, I, v. 1: Canto las armas y al héroe]. Horacio: Musa lyrae solers et cantor Apollo [Epistola a los Pisones, v. 407: la Musa diestra con la lira y el cantor Apolo]. Es así que la poesía es cierta especie de música, cuya modulación se representa en la artificiosa colocación de palabras y sílabas, como la de la música ordinaria en la ordenada positura de las notas; y nada de esto hay en la prosa (CEC, V, XXI, 17; 1760).

La consideración de "entusiasmo» y «versificación» como constitutivos esenciales de la poesía no es exclusiva de Feijoo: otros preceptistas del momento apuntarán en la misma dirección. No se presta precisamente a controversia el hecho de que la "versificación" deba ser rasgo sine qua non de la poesía, así que el criterio feijoniano es, en lo concerniente a este asunto, compartido por muchos otros autores. Pedro Verdugo, en su "Disertación sobre el numen poético" participa de este criterio $^{10}$; Luzán precisa en su definición de la poesía que debe estar «hecha con versos", pues "se prueba ser el verso necesario a la poesía " ${ }^{11}$. Jovellanos, más tarde, entenderá que todo poema se construye mediante un lenguaje "formado por lo común en números regulares» y que, si bien "hay obras en prosa que poseen los principales constitutivos de la poesía», es el verso "una propiedad de la poesía que la caracteriza y la distingue de las composiciones prosaicas» ${ }^{12}$. Por su parte, en sus Instituciones poéticas (1793), Santos Díez González defenderá que la poesía

10. Marín, Nicolás. "La Disertación sobre el numen poético de Don Pedro Verdugo (texto inédito de 1716)». Boletín del Centro de Estudios del Siglo XVIII, 1983, 10-11, pp. 69-84; el dato en pp. 71-72. Sobre esta "Disertación", debe verse el estudio MARín, Nicolás, "Poesía y ciencia moderna en un texto de 1715». En Alarcos, Emilio, et al. (eds.). Serta Philologica F. Lázaro Carreter. Natalem diem sexagesimum celebranti dicata. 1. a ed., vol. III, Madrid: Cátedra, 1983, pp. 317-327.

11. Citamos por LuzÁn, Ignacio de. La poética, edición de Russell P. SEBold. 3. ${ }^{a}$ ed., Madrid: Cátedra, 2008. La cita en p. 191.

12. Jovellanos, Melchor Gaspar de. "Lecciones de Retórica y Poética». Curso de Humanidades castellanas. En Obras, tomo I. 1. ${ }^{\text {a }}$ ed., Madrid: Atlas, 1963, pp. 137b-138a, BAE. 
se diferencia de todas las demás artes imitativas y se singulariza respecto de ellas en valerse del verso ${ }^{13}$.

En lo tocante al papel fundamental del «entusiasmo» para particularizar a la poesía, podemos decir que este concepto era moneda común en el siglo. Verdugo lo asimiló al numen y defendió su papel central ${ }^{14}$. Tampoco Jovellanos dudó al afirmar que la poesía "es el lenguaje de la pasión", pues se dirige "a la imaginación y a las pasiones», de forma que «el ánimo del poeta avivado» despierta sus sentidos y «enciende su imaginación", lo que acaba por traducirse en «una elevación" de su estilo ${ }^{15}$. Todavía más contundente se manifestará Antonio Burriel cuando en el Compendio del Arte Poética (1757) abunde en que no hay poesía sin «furor" o "entusiasmo». Explica Burriel que, desposeídos de ese furor, los poetas no lograrán alcanzar más que muy medianas cotas, porque "faltando aquella conmoción de la fantasía con que se levanta [el alma] sobre sí misma y sobre todas las cosas, no queda [el poeta] capaz de las grandes y sublimes ideas que de allí nacen». Además, y como colofón, «esta elevación y vehemencia en concebir las cosas que nace del furor poético es lo que más distingue a los poetas entre sí, tan necesaria que sin ella no puede haber cosa grande» ${ }^{16}$.

Pero demos ahora un pequeño salto atrás. Cuando Feijoo decide proponer su definición personal de la poesía en 1760 (CEC, V, XXIII) lo hace movido por la necesidad de justificar una de sus más antiguas afirmaciones: la de que la ficción o fábula no solo no es necesaria en el poema, sino que es incluso contraproducente. Cuando Feijoo se ocupa de determinar el "constitutivo esencial de la poesía», tres son los elementos que de partida se plantea como posibles rasgos distintivos del género: «entusiasmo», «versificación» y «fábula». Feijoo había atacado fuertemente la poesía ficcional y había venido manteniendo desde hacía veinte años una larga polémica acerca del surgimiento de la fábula en poesía ${ }^{17}$. Cansado de ello a estas alturas, a la provecta edad de ochenta y cuatro años, Feijoo afirma que a la postre la discusión acerca de la esencia de la poesía «es una mera cuestión de nombre»; y concede que la no ficción no tiene por qué ser un constitutivo esencial de la

13. Citamos por Checa Beltrán, José. Pensamiento literario del siglo XVIII español. 1. ${ }^{a}$ ed., Madrid: CSIC, 2004, pp. 171-172.

14. Marín, Nicolás. "La Disertación sobre el numen poético de Don Pedro Verdugo (texto inédito de 1716)", p. 75.

15. Jovellanos, Melchor Gaspar de. "Lecciones de Retórica y Poética», p. 137b

16. Citamos por CHeCA Beltrán, José. Pensamiento literario del siglo XVIII español, pp. 172-173.

17. No debe dejar de consignarse que la postura de Feijoo comparte una gran cantidad de rasgos con los sostenidos por Pedro Verdugo en su "Disertación sobre el numen poético", pues el poeta granadino también se muestra contrario a quienes erróneamente "para diferenciar las obras poéticas de las históricas quieren que el poeta indispensablemente haya de fingir la mayor parte de sus narraciones y por ese defecto excluyen del Parnaso a Lucano", pues, aclara Verdugo, "el poeta busca lo admirable posible, y aunque no se obliga a la verdad particular, como el historiador, no contradice a las verdades generales», MaRín, Nicolás. "La Disertación sobre el numen poético de Don Pedro Verdugo (texto inédito de 1716)", p. 77. 
poesía; no obstante, tampoco puede decirse ni mucho menos que Feijoo dé su brazo a torcer, pues finaliza su carta con una afirmación desconcertante pero fundamental, a saber: «sería mucho más sensible la falta de los historiadores que la de los poetas» (CEC, V, XXIII, 24; 1760).

¿Qué tienen que ver los historiadores con todo esto? Ahí radica la clave del llamado "Pleito de Lucano", que lejos de enfrentar a Lucano con Virgilio, en realidad dirime si en la poesía debe predominar o no la intencionalidad didáctica, dado que, aunque Feijoo solo hable de constitutivos esenciales cuando se refiere a «entusiasmo» y "versificación", de sus diversos escritos sobre poética se desprende que hay al menos otros tres constitutivos que el considera igualmente indisociables del género poético: la ausencia de fábula, la función docente y la naturalidad.

\section{UNA POESÍA SIN FICCIÓN: EL PLEITO DE LUCANO Y LA TRASCENDENCIA DEL PRODESSE}

Según la interpretación tradicional del Pleito, la preferencia feijoniana de Lucano sobre Virgilio (TCU, IV, XIV, § XV, 39; 1730) se habría debido al mal gusto literario del autor del Teatro crítico, como defendió Menéndez Pelayo, quien entendió, asimismo, que Feijoo «en el fondo sostenía la causa de Lucano por el hecho de haber sido Lucano español ${ }^{18}$. Esta inclinación de Feijoo por la épica del cordobés también se ha explicado mediante un segundo motivo, a saber, la falta de sensibilidad y formación estética de Feijoo, quien, para Menéndez Pelayo, no sería capaz de discernir "las razones de arte que hacen que Virgilio sea un poeta perfecto en su línea y enteramente adorable, y Lucano solo un gran poeta de decadencia, monótono y fatigosísimo de leer»" ${ }^{19}$. Por ello, a causa de su "perverso gusto", Feijoo no podría ser tomado en consideración en cuestiones de poética. Según Menéndez Pelayo «toda gran cualidad lleva consigo aparejado algún defecto gravísimo ${ }^{20}$, y con su nula sensibilidad literaria estaría pagando Feijoo su gran capacidad razonadora. Muy próximo a estos planteamientos se manifestaría décadas más tarde Benito Varela Jácome ${ }^{21}$.

Tales apreciaciones quizá sean las más injustas y las que han ejercido una influencia más nociva de todas las que Menéndez Pelayo hizo acerca de Feijoo; sea como fuere, conviene dejar dicho desde ya que las razones que hicieron que Feijoo declarase su preferencia por Lucano ante Virgilio son más complejas que su

18. MenéndeZ Pelayo, Marcelino. Historia de las ideas estéticas en España: el siglo XVIII. 1. ${ }^{a}$ ed., Santander: CSIC, 1940 (ed. original de 1886), p. 210.

19. MenéndeZ Pelayo, Marcelino. Historia de las ideas estéticas: el siglo XVIII, p. 210.

20. MenéndeZ Pelayo, Marcelino. Historia de las ideas estéticas: el siglo XVIII, p. 212.

21. VArela Jácome, Benito. "Las preocupaciones literarias del Padre Feijoo". Cuaderno de Estudios Gallegos, 1968, XVIII, 70, pp. 155-174. Varela Jácome se limita a resumir las apreciaciones de Menéndez Pelayo, añadiendo únicamente que la preferencia de Feijoo por Lucano se debe a «su concepción de la poesía" y a "su postura estética, barroca", añadiendo de paso que todo ello manifiesta su "insensibilidad para apreciar la genial poesía virgiliana» (citas en p. 164). 
nacionalidad $^{22}$, lo que no quiere decir que Feijoo no tuviese en altísima estima a Virgilio. De hecho, Virgilio aparece citado en los ensayos de Feijoo mucho más a menudo que Lucano. Es más, recordemos que Feijoo escribió sobre el de Mantua que «su majestad heroica me enamora, su grandilocuencia poética me hechiza: aquellos sonoros y soberanos golpes que a trechos deja caer como desde la cumbre del Olimpo sobre la mente del que lee totalmente me arrebatan» (TCU, IV, XIV, $\S \mathrm{XV}, 42 ; 1730)^{23}$.

Ya Morayta, en un texto mucho menos conocido y citado de lo que mereciera, ofreció una explicación del Pleito purgada de clichés y centrando el foco de debate en la relación entre poesía e historia ${ }^{24}$. Asimismo, es de justicia consignar aquí que en su trabajo de 1932 dedicado a "Las ideas estéticas del Padre Feijoo", Santiago Montero Díaz se separa de Menéndez Pelayo en lo relacionado con la interpretación del Pleito de Lucano, pues considera que "sería extraño que un hombre tan ponderado y sereno" como Feijoo se dejase llevar "por simple prurito nacional", de donde deduce que "otros motivos más hondos» deben justificar su preferencia. Montero Díaz sostiene que Feijoo era proclive a Lucano por no condescender este con la ficción y por su estilo tan elaborado, lo que no impidió que le pusiese algún reparo ni le condujo tampoco a rechazar a Virgilio o aminorar sus méritos poéticos ${ }^{25}$. Gaspard Delpy, por su lado, estudió asimismo al Pleito en su

22. Pese a todo, no debe perderse de vista el contexto en que la defensa de Lucano es emprendida: los dos discursos acerca de las "Glorias de España» (TCU, IV, XIII y XIV; 1730) obedecen a una muy concreta reivindicación de la cultura española en el marco de la defensa del valor de la ciencia y las artes desarrolladas en sueño español. Para lo referido a esta operación cultural típicamente dieciochesca, puede verse Álvarez BARRIENTOS, Joaquín. Los bombres de letras en la España del siglo XVIII. Apóstoles y arribistas. 1. ${ }^{a}$ ed., Madrid: Castalia, 2006; en lo referido a Feijoo, LorEnzo ÁlvarEZ, Elena de; Olay VAldés, Rodrigo y García DíAZ, Noelia (eds.). Lidiando con sombras. Antología de Benito Jerónimo Feijoo. 1. ${ }^{a}$ ed., Gijón: Trea, 2014, pp. 206-218. Un claro ejemplo de cómo diversas polémicas literarias y preceptivas acabaron tiñéndose de ribetes políticos en el momento se halla en GARRIDO PALAZÓN, Manuel. "Translatio imperii, translatio studii: el gusto español en la polémica clasicista italofrancesa del primer siglo XVIII». En CHECA BeLTRÁN, José (ed.). Lecturas del legado español en la Europa ilustrada. 1. ${ }^{a}$ ed., Madrid-Frankfurt: Iberoamericana/Vervuert, 2012, pp. 41-66.

23. Muchísimos testimonios cabe aducir en favor de Virgilio de pluma de Feijoo, pero hemos decidido entresacar otro particularmente significativo en la medida en que el benedictino expresa su preferencia por Virgilio en comparación con otro poeta que también era de su agrado, y que ha sido, además, considerado no pocas veces el sucesor natural de Lucano: Juan de Mena. Así, explicando las diferencias que hay entre distintos profesionales de un mismo campo (particularmente, el de la medicina), propone Feijoo el siguiente ejemplo: "Compárese la divina Eneida de Virgilio con las coplas de Juan de Mena, o de otro versificador de los muchos que hay [...]. ¿Quién no ve que entre cualesquiera de los dos extremos que he señalado hay una distancia tan enorme que es divisible en centenares y aun millares de grados, y por consiguiente que hay la misma en la habilidad de los artífices o autores?» (CEC, V, XXI, § V, 27; 1760).

24. Morayta, Miguel. El Padre Feijoo y sus obras. 1. ${ }^{a}$ ed., Valencia: P. Sempere y Compañía, s. f. [¿1912?, pero escrito en 1876], p. 128.

25. Montero Díaz, Santiago. "Las ideas estéticas del Padre Feijoo". Boletín de la Universidad de Santiago de Compostela, 1932, IV, 15, pp. 3-95; el dato en pp. 42-44. 
memorable monografía feijoniana. Para el francés, es el amor por la exageración, si no por la paradoja, lo que lleva a Feijoo a mostrar su predilección por Lucano ${ }^{26}$, lo que, con matices, compartirá McClelland, que verá en la preferencia feijoniana una demostración de su amor por pensar libremente. Aunque reconstruye con precisión la argumentación feijoniana, y no olvida atender a la polémica que siguió a la reivindicación del benedictino, no pretende explicar a qué obedece la defensa de Lucano, si bien su lectura aparece ya completamente purgada de la conceptualización sobre el particular debida a Menéndez Pelayo ${ }^{27}$.

Algo parecido le sucede a Vittorio Borghini, quien inicia su análisis del Pleito, al igual que Delpy, explicitando su opinión al respecto, y de ahí que especifique que Feijoo "cade in un errore comunissimo", a saber, "sentir grande un poeta non in virtù della sua pura arte», sino de su cualidad para representar "un gusto» $\mathrm{O}$ «una scuola correnti»; más adelante, incluso, anota que Feijoo «no mostrò eccesiva chiarezza d'idee» al respecto de la literatura. Aunque da cuenta del texto de Feijoo deteniéndose en el núcleo del Pleito, es decir, si la fábula es tolerable, y hasta qué punto, en poesía, no pierde la oportunidad de discutir una vez más a Feijoo al llamar la atención sobre el hecho de que, a nuestros ojos, Lucano se valió igualmente de la ficción que Virgilio: "tutti riconoscamo in lui un creatore». Sea como fuere, creemos que Borghini acierta a plantear la raíz del problema cuando relaciona la "condama della fizione" con el "nuove spirito utilitarista del Settecento" ${ }^{28}$. Otros autores posteriores, como Pérez Rioja ${ }^{29}$ u Otero Pedrayo ${ }^{30}$ se expresaron en muy parecidos términos.

No debe pasarse por alto el trabajo de Xosé Antonio López Silva ${ }^{31}$, de muy reciente publicación, que traza toda una genealogía histórica del Pleito de Lucano en España desde la inicial polémica epistolar de Cascales y González de Sepúlveda hasta la influencia que en Feijoo pudo ejercer la aprobación del Padre Cortés

26. Delpy, G. L'Espagne et l'esprit européen. L'œevre de Feijoo (1725-1760). 1. a ed., París: Hachette, 1936, pp. 200-209.

27. McClelland, Ivy L. Benito Jerónimo Feijoo. 1. ${ }^{a}$ ed., New York: Twayne, 1969, pp. 100-102.

28. Borghini, Vittorio. Problemi d'estetica e di cultura nel Settecento spagnolo (Feijoo-LuzánArteaga). 1, ${ }^{a}$ ed., Génova: Tipografia Opera, 1958, pp. 30-37; citas en pp. 30-31.

29. Pérez Rioja, José Antonio. Proyección y actualidad de Feijoo. 1. ${ }^{a}$ ed., Madrid: Instituto de Estudios Políticos, 1965, pp. 80-81. El autor se limita a plantear la polémica como oposición entre historia y ficción.

30. Otero Pedrayo, Ramón. El Padre Feijoo, su vida, doctrina e influencias. 1. a ed., Orense: Instituto de Estudios Orensanos, 1972, pp. 488-500. Otero Pedrayo subraya que lo que se oculta tras la preferencia feijoniana no es un gusto pervertido ni un nacionalismo insano, sino su defensa de la poesía desprovista de ficción.

31. López Silva, Xosé Antonio. "Feijoo contra los virgilianistas. La polémica sobre Lucano en el XVIII en España». En García JuRAdo, F., GonZÁlez Delgado, R. y GonZÁlez González, R. (eds.). La bistoria de la Literatura Grecolatina en España: de la Ilustración al Liberalismo (1778-1850). 1. ${ }^{\mathrm{e}}$ ed., Málaga: Universidad de Málaga, Anejos de Analecta Malacitana, 2013, pp. 375-394. 
Osorio a la traducción de la Farsalia de Juan de Jáuregui ${ }^{32}$, traducción esta que Feijoo manejó (TCU, I, XV, § V, 20; 1726). Asimismo, López Silva recorre cumplidamente el devenir de la contienda feijoniana en sus variadas ramificaciones externas hasta finales del siglo XVIII. Con respecto a las ideas debatidas, López Silva vuelve a insistir en que la clave se halla en "el estatuto de la ficción en la poesía ${ }^{33}$.

$\mathrm{Y}$ es que no cabe duda de que el planteamiento del Pleito proviene de una larga polémica desarrollada en Europa a lo largo de los siglos precedentes en el marco de configuración de la poética clasicista, a saber, la Querella de los Antiguos y los Modernos ${ }^{34}$, con respecto a la que muchas de las ideas literarias de Feijoo no son sino tomas de posición ${ }^{35}$. En definitiva, estamos ante un debate con

32. Sobre este particular, cita un trabajo suyo en prensa (vid. López Silva, Xosé Antonio. Feijoo contra los virgilianistas. La polémica sobre Lucano en el XVIII en España, p. 380, n. 20). Efectivamente, un cotejo del texto feijoniano y el paratexto de Cortés Osorio ofrece muy interesantes concomitancias. Cfr. La Farsalia: Poema Español / Escrito por don Juan de Jáuregui y Aguilar, Caballero de la Orden de Calatrava, Cavallerizo de la Reyna Nuestra Señora, Doña Isabel de Borbón / Sácale a luz Sebastián de Armendáriz y le dedica a su S.R.Y.C.M con la protección del excelentísimo Señor Duque de Medinaceli, Segorbe y Alcalá, 1. ${ }^{a}$ ed., Madrid: Lorenzo García, 1684, pp. [29-32].

33. López Silva, Xosé Antonio. "Feijoo contra los virgilianistas. La polémica sobre Lucano en el XVIII en España», p. 382.

34. Con respecto al marco general de la Querelle, son de especial relevancia los trabajos clásicos de HigHET, Gilbert. La tradición clásica. Influencias griegas y romanas en la literatura occidental, vol. I. 1. ${ }^{a}$ ed. española [ed. inglesa original de 1949], México D. F.: Fondo de Cultura Económica, 1954, pp. 411-449; Borgehoff, E. B. O. The freedom of French Classicism. 1. a ed., Princeton: Princeton University Press, 1950 y el de Fumaroli, Marc. L'Âge de l'Éloquence. Rhétorique et res literaria de la Renaissance au seuil de l'époque classique. 1. ${ }^{\mathrm{a}}$ ed., Paris: Albin Michel; igualmente, LECOQ, Anne Marie (ed.). La querelle des anciens et des modernes: XVIIе-XVIII siècles; précédé de Les abeilles et les araignées: essai de Marc Fumaroli; suivi d'une postface de Jean-Robert Armogathe. 1. ${ }^{a}$ ed., Paris: Folio, 2001; más recientemente, Minor, Vernon Hyde. The death of the Baroque and the rhetoric of good taste. 1. ${ }^{a}$ ed., Cambridge: Cambridge University Press, 2006.

35. La relación de determinadas ideas literarias de Feijoo con las del debate de la preceptiva europea de su tiempo ha venido estudiándose circunscrita al respecto de los conceptos de "gusto" (TCU, VI, XI: 1734) y "no sé qué» (TCU, VI, XII; 1734). Puede verse para ello, inicialmente, Croce, Benedetto. Estética. Filosofía como ciencia del espíritu. 2. ${ }^{a}$ ed. española [1. ${ }^{a}$ ed. de 1912; ed. original en italiano de 1902], Madrid: Francisco Beltrán, 1926, pp. 230-231; y luego, mucho más desarrollado, Borghini, Vittorio. Problemi d'estetica e di cultura nel Settecento spagnolo (Feijoo-Luzán-Arteaga), pp. 14-20; y SAmonà, Carmelo. "I concetti di "gusto" e di "no sé qué" nel Padre Feijoo e la Poetica del Muratori». Giornale Storico della Letteratura Italiana, 1964, 33, pp. 117-124, complementados después, atendiendo a otros autores, por NAVARro DE Adriaensens, José María. "Je ne sais quoi": BouhoursFeijoo-Montesquieu». Romanistisches Jabrbuch, 1970, XXI, pp. 107-115; ARCE, Joaquín. La poesía del siglo ilustrado, 1. ${ }^{a}$ ed., Madrid: Alhambra, 1981, pp. 188-194 y, más recientemente, por VALERO, José A. "Las ideas estéticas de Feijoo». Ideologies and Literature, 1988, III, pp. 63-113. Algún dato contextual ofrecen también PINTO, Mario di. Studi su la cultura spagnola nel settecento. 1. ${ }^{a}$ ed., Nápoles: Edizioni Scientifiche Italian, 1964, pp. 142-148; y PAOLETTI, Catherine. «Benito Jerónimo Feijoo ou les variants d'un je-ne-sais-quoi». En FeIJoo, Benito Jerónimo. Le je-ne-sais-quoi. 1. a ed., traducción y presentación de C. P., Cahors: Editions de L'eclat, 1989, pp. 9-21. En la misma línea, resultan mucho más completos e interesantes los trabajos compilatorios de D'Angelo, Paolo y VelotTi, Stefano (eds.). "Il «non so che». Storia di una idea estetica. 1. ${ }^{a}$ ed., Palermo: Aesthetica edizioni, 1997 (para Feijoo, vid. pp. 21-27, 
siglos de tradición literaria: la licitud o no de la fantasía en la imitación de la naturaleza y su pertinencia en el género épico.

Sin pretender, ni mucho menos, agotar el tema, podemos recordar que Aristóteles dejó dicho en su Poética que «el poeta debe ser más poeta de fábulas que de versos, tanto más cuanto que es poeta por la mímesis y mimetiza las acciones. Y si llega un momento en que sus temas sean cosas ya ocurridas, no será menos poeta, pues nada impide que algunas de las cosas que han ocurrido sean verosímiles» (IX, 1451b) ${ }^{36}$. Esto es, Aristóteles admite la representación de lo fabuloso, pero no desdeña la de lo real, siempre y cuando una y otra se atengan a lo verosímil. La tradición poética clásica discutió estos postulados, a menudo restringiendo la abierta postura de Aristóteles, de lo que son buen ejemplo, entre otras, las matizaciones de Robortello y Castelvetro, quienes se mostraron proclives a la representación de lo maravilloso, o, después de ellos, Jacopo Mazzoni ${ }^{37}$. Al respecto del mismo tema, la polémica suscitada por los excesos imaginativos del Orlando furioso llevó a Tasso a posicionarse en favor de una épica que trabajase a partir de sucesos históricos y en la que la irrupción de lo maravilloso se limitase a las creencias religiosas del lector, lo que defendió en sus Discorsi dell'arte poetica y trató de ejemplificar en su Jerusalén $n^{38}$; los preceptistas españoles, de López Pinciano a Cascales, se hicieron rápidamente eco de la polémica; tanto uno como otro mantuvieron en lo esencial la tesis de Tasso, que a partir de la lectura del primero llega asimismo a Cervantes ${ }^{39}$. Paralelamente, en el marco de la Querelle francesa, la discusión acerca de la introducción de elementos maravillosos se contaminaba, como en Tasso, de criterios morales emparentados con la religión: los modernos criticaban en las epopeyas clásicas la irrupción de deidades insostenibles; los antiguos sencillamente reprochaban la falta de verosimilitud de algunas de las nuevas

49-58, 109-121); y Russo, Luigi (ed.). Il Gusto. Storia di una idea estetica. 1. ${ }^{a}$ ed., Palermo: Aesthetica edizioni, 2000 (para Feijoo, vid. pp. 11-34, 209-217), que atienden minuciosamente a la importancia del pensamiento feijoniano en el desarrollo de ambos conceptos en el marco del discurso literario europeo. Por su parte, en KÖHLER, Erich. "Der Padre Feijoo und das "no sé qué". Romanistisches Jahrbuch, 1955-1956, VII, pp. 272-290 y, más detalladamente, en PORQUERAS MAYO, Alberto. "El "no sé qué" en la literatura española». Temas y formas de la literatura española. 1. ${ }^{\text {a }}$ ed., Madrid: Gredos, 1972, pp. 11-59 puede encontrarse un profundo rastreo de tal concepto en el decurso de la literatura española, muy ampliado y puesto al día para todo lo relativo a la literatura del siglo ilustrado en JACOBs, Hemut C. Belleza y buen gusto. La teoría de las artes en la literatura española del siglo XVIII. 1. ${ }^{a}$ ed. española [ed. alemana original de 1996], Madrid-Frankfurt: Iberoamericana/Vervuert, 2001 (para Feijoo, vid. pp. 42-46, 142-155, 190-197) y en HonTANilLa, Ana. El gusto de la razón. Debates de arte y moral en el siglo XVIII español. 1. ${ }^{a}$ ed., Madrid-Frankfurt: Iberoamericana/Vervuert, 2010 (para Feijoo, vid. pp. 121-128).

36. Aristóteles/Horacio. Artes poéticas. 1. ${ }^{a}$ ed., edición bilingüe de Aníbal González, Madrid: Taurus, 1987, p. 60.

37. García Berrio, Antonio. Introducción a la poética clasicista: Cascales. 1. ${ }^{\mathrm{a}}$ ed., Barcelona: Planeta, 1975, pp. 117-118

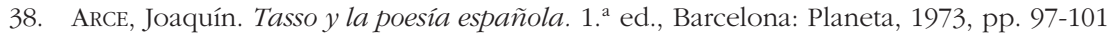

39. GARCía Berrio, Antonio, Introducción a la poética clasicista: Cascales, pp. 114-125. 
epopeyas, caso del Orlando, independientemente de que en ellas no concurrieran los dioses paganos ${ }^{40}$.

Ahora bien, si no conviene perder de vista este caldo de cultivo en el discurrir de la evolución preceptiva desde el Xvi, lo cierto es que Feijoo la hereda y recibe muy probablemente a partir de la lectura de Muratori ${ }^{41}$, como se irá viendo; no debe perderse de vista tampoco que el propio Muratori asimismo participa de las ramificaciones setecentistas italianas de la Querelle ${ }^{42}$. El de Vignola, en el duodécimo capítulo de su Della perfetta poesia italiana (1706) atiende a la introducción de lo «imposible» en la poesía ${ }^{43}$. Para Muratori, la utilización de elementos maravillosos sin función aparente en el poema épico únicamente podría justificarse por su carácter cómico; en el caso de que las inverosimilitudes aparezcan en un

40. Fumaroli, Marc. "Les abeilles et les araignées». En LECOQ, Anne Marie (ed.). La querelle des anciens et des modernes: XVIIe-XVIIIe siècles; précédé de Les abeilles et les araignées: essai de Marc Fumaroli; suivi d'une postface de Jean-Robert Armogathe, pp. 169-178.

41. Castelvetro es citado en CEC, V, XIX, 11; 1753 y Mazzoni en CEC, II, I, 2; 1742; Robortello, Cascales y López Pinciano, nunca (por «Pinciano» alude Feijoo siempre a Hernán Núñez de Toledo). Para Tasso, véase Olay VAldés, Rodrigo. "Reconstrucción del canon poético en el ensayo de Feijoo", n. 103. Por su parte, ya Gaspard Delpy advirtió la ocurrencia de citas muratorianas en la obra de Feijoo (Delpy, G. L'Espagne et l'esprit européen. L'oevre de Feijoo (1725-1760), pp. 340-341), mencionado por Feijoo en CEC, I, XXIII, 36; 1740; CEC, II, XXVI, 41: 1742; JR, § 1; 1749. En la nota 39 ofrecemos numerosa bibliografía relativa a la relación entre las ideas literarias de Feijoo y Muratori. Para la presencia del toscano en la literatura española, véanse MESTRE, Antonio. «Muratori y la cultura española». En VV. AA. La fortuna di L. A. Muratori. 1. ${ }^{a}$ ed. Florencia: Olschki, 1975, pp. 173-220; MAZzOCCHI, Giuseppe. "L. A. Muratori e la letteratura spagnola». Il confronto letterario, 1987, IV, pp. 3-33; Mazzocchi, Giuseppe. «L. A. Muratori e la cultura spagnola». Studi Settecenteschi, 1990, XI, pp. 161-177; Froldi, Rinaldo. "Ludocivo Antonio Muratori nella cultura spagnola». En VV. AA. Italia e Spagna nella cultura del' $700,1 .^{a}$ ed. Roma: Accademia Nazionale dei Lincei, 1992, pp. 19-33. Otros preceptistas aludidos - pero muy rara vez en relación con discusiones teórico-literarias- son Boileau, citado como autor de gran relevancia en TCU, IV, XIV, § XXII, 109; 1730; Rapin, acerca de diversos temas de naturaleza esencialmente teológica y dialéctica, en TCU, I, XVI, Adiciones, 10; 1740; TCU, II, I, § II, 12; 1727; TCU, IV, VIII, § I, 3; 1730; TCU, VII, XII, § I, 6; 1736; CEC, I, XXII, 5; 1742; CEC, II, XIII, 14, 19, 41, 85; 1745; CEC, IV, XIII, 16, 17; 1753; Scaligero, en el marco de discusiones de diversa índole, en TCU, III, VII, § VI, 45; 1729; TCU, IV, § X, 29; 1730; TCU, IV, XIV, § XV, 39, Adición, 1 y 7; 1740; TCU, VI, IV, § VI, 25; 1734; TCU, VI, IV, § V, 26; 1734; TCU, VI, X, § I, 4 y 5; 1734; CEC, II, VII, Advertencia; 1745; CEC, IV, XII, 9; 1753; CEC, IV, XVIII, 58; 1753; Tesauro, en TCU, VII, Prólogo; 1736; TCU, VII, 10, § I, 6; 1736; CEC, I, Dedicatoria; 1742; y Bouhours, también al paso de una variada temática, en TCU, VI, X, § XIV, 34; 1734; CEC, II, VII, 25; 1745; CEC, II, VIII, 32; 1745; CEC, IV, XIII, 2; 1753; CEC, IV, XXVI, 13; 1753. Para el estudio de las fuentes francesas de Feijoo sigue siendo fundamental DeLPY, Gaspard, Bibliographie des sources françaises de Feijoo, París: Hachette, 1936 (1. a ed.).

42. CotTignoli, Alfredo. "Antichi e Moderni in Arcadia". En SACCENTI, M. (ed.). La Colonia Renia: Profilo documentario e critico dell Arcadia bolognese. 1. ${ }^{\text {a }}$ ed. Modena: Mucchi, 1988, pp. 53-69; así como, también dedicado específicamente a la Querelle italiana, Fumaroli, Marc. "Les abeilles et les araignées». En LECOQ, Anne Marie (ed.). La querelle des anciens et des modernes: XVIIe-XviIIe siècles; précédé de Les abeilles et les araignées: essai de Marc Fumaroli; suivi d'une postface de Jean-Robert Armogathe, particularmente las pp. 24-91.

43. Muratori, Ludovinco Antonio. Della perfetta poesía italiana, ed. de Ada Ruschioni. 1. a ed., Milán: Marzorati Edizione, 1971, 2 vols. (el capítulo citado en vol. 1, pp. 147-153). 
poema serio, entonces, dice Muratori, producen «nausea o dispiacere e accusiam d'ignoranza o di poca accortezza il poeta "44. Más adelante, Luzán beberá de tales planteamientos ${ }^{45}$ cuando afirme asentar "la verdad por base y fundamento de la belleza poética " ${ }^{46}$, haciéndose buena cuenta, con Muratori, de que el poeta tiene la potestad de trabajar con la "verdad cierta", esto es, la verdad empírica o histórica, y la "verdad probable o verosímil», esto es, la ficción plausible ${ }^{47}$. De tal forma, la poesía podrá para Luzán contener lo falso, pero no lo inverosímil, siempre que sirva a la expresión de alguna verdad de provechosa enseñanza.

Pretendiendo dar respuesta a estos interrogantes, José Checa Beltrán ha explicado cómo «en el fondo de esta disputa late el asunto que plantea si la ficción es requisito necesario para que haya poesía. Los defensores de Virgilio así lo estimaban, degradando de la condición de poeta a Lucano por su falta de ficción ${ }^{48}$. Pero trascendental de la aportación de Checa es que añada que "llevado por el ardor de la disputa acerca de lo real y lo ficticio, Feijoo acaba atribuyendo más importancia a los historiadores que a los poetas ${ }^{49}$. Y todavía matizará levemente este juicio al precisar que Feijoo da más importancia a los historiadores, sí, «y mayor relevancia social, ${ }^{50}$.

Pero ¿por qué prefirió Feijoo la no ficción? ¿Por qué dar «mayor relevancia social» a historia que a poesía? Volvamos al texto en que se origina el pleito - Glorias de España (segunda parte)»; TCU, IV, XIV; 1730-, en que Feijoo, al paso que comenta que ninguna provincia dio a Roma tantos y tan buenos escritores como Hispania, cita como ejemplos preclaros de nuestras letras a «Silio Itálico ${ }^{51}$, Lucano, Marcial, Séneca el Trágico, Columela, Latroniano y otros». Entonces (TCU, IV, XIV, $\S \mathrm{XV}, 39 ; 1730)$ explica Feijoo que sendas cumbres alcanzaron Marcial y Lucano, respectivamente la de lo cómico y lo heroico, y es en este momento clave cuando

44. Muratori, Ludovinco Antonio. Della perfetta poesía italiana, ed. de Ada Ruschioni, vol. 1, p. 149 .

45. De hecho, Luzán cita explícitamente a este respeto a Muratori: LuZÁN, Ignacio de. La poética, edición de Russell P. Sebold, p. 257, en alusión a MuRATORI, Ludovinco Antonio. Della perfetta poesía italiana, ed. de Ada Ruschioni, vol. 1, pp. 119-128.

46. LuZán, Ignacio de. La poética, edición de Russell P. Sebold, p. 257. Un comentario de todo ello puede verse en CHECA BeLtrán, José. «Verosimilitud y maravilla en la poética española dieciochista". Anthropos, 1994, 154-155, pp. 32-38.

47. LuZÁn, Ignacio de. La poética, edición de Russell P. Sebold, p. 258.

48. Checa Beltrán, José. "Teoría literaria». En Aguilar Piñal, Francisco (ed.). Historia literaria de España en el siglo XVIII. 1. a ed., Madrid: Trotta-CSIC, 1996, pp. 443-444.

49. Checa Beltrán, José. "Teoría literaria», p. 444.

50. Checa Beltrán, José. Razones del buen gusto. Poética española del Neoclasicismo. 1. a ed., Madrid: CSIC, 1998, p. 64.

51. Gregorio Mayans, siempre tan meticuloso, afeó a Feijoo el haberse confundido al considerar hispano a Silio Itálico: «hace V. Rma. español a Silio Itálico [lo hace de hecho en tres ocasiones: TCU, I, XII, § 1, 4; 1726; TCU, IV, XIII, § 2, 5; 1739; y TCU, IV, XIV, § XV, 38; 1730]. Ese es error común». Mestre, Antonio. "Correspondencia Feijoo-Mayans en el Colegio del Patriarca". Anales del Seminario de Valencia, 1964, IV, 8, pp. 149-185; la cita en p. 176. 
añade que si Lucano no fue tan celebrado como mereció, se debió al inmensurable favor de que siempre gozó Virgilio, con quien es inevitable comparar al poeta cordobés por ser uno y otro los dos grandes autores épicos de la latinidad. A ojos del benedictino, pesó sobre Lucano la enorme fama de Virgilio no menos que su propia condición de extranjero en Roma; y recalca que no puede reprochársele a Lucano haber prescindido de la fábula en su Farsalia, porque ello es antes gala que defecto.

Aprecia entonces que la reelaboración histórica acometida por Lucano en la Farsalia es más meritoria que el uso virgiliano de la fábula: «sería sin duda una grande infamia de la poesía profesar antipatía irreconciliable con la verdad». Y aun remacha: "lo difícil es dar a una historia verdadera todo el atractivo de que es capaz la fábula. ¿Qué dificultad tiene el fingir?» (TCU, IV, XIV, § XV, 40; 1730), lo que hace acompañar después con un par de alusiones a dos momentos particularmente indecorosos de la Eneida, lastrados, según Feijoo, por su uso de la ficción (no debe pasarnos desapercibido que exactamente esos dos ejemplos son igualmente aducidos por Muratori) ${ }^{52}$.

A estas afirmaciones de Feijoo sigue una larga adición posterior, de 1740, incluida en el tomo noveno o Suplemento del Teatro crítico universal, originada por lo polémico de sus preferencias y por las repercusiones que ocasionaron entre los detractores del benedictino, a las que aludiremos brevemente más delante. En esas páginas, Feijoo razona demoradamente su elección. Y es llegado este punto cuando se transparenta la importancia fundamental que otorga a la no ficción en el poema y, como consecuencia de ella, a su intencionalidad didáctica.

Concede a sus impugnadores que Lucano padece el defecto de «la prolijidad y amplificación algo tediosa en varias partes del poema, nacida de que no era dueño del ímpetu que le arrebataba para reprimirle oportunamente» (TCU, IV, XIV, $\S \mathrm{XV}, 39$, Adición, 4; 1740), pero otros defectos halla en Virgilio. El más grave, sin duda, el hecho de que en la Eneida Virgilio hace un uso continuado de la ficción.

El quid está en que Feijoo, como ya hemos visto, descree de que la ficción sea uno de los constitutivos esenciales de la poesía, incluso considera que "bien lejos de ser la ficción de la esencia de la poesía, sin temeridad se puede decir que es corrupción suya» (TCU, IV, XIV, § XV, 39, Adición, 9; 1740), lo que argumenta concienzudamente.

En primer lugar, considera que grandes poemas latinos nada tienen que ver con la ficción: «realmente, si la ficción es de esencia de la poesía, hemos de descartar de poetas a Lucrecio, el cual en sus versos solo escribió una filosofía que

52. Feijoo se refiere al enamoramiento de Dido por Eneas, que cree en primer lugar inverosímil y en segundo lugar indecente [Eneida, IV, vv. 160-164], ejemplo ya ofrecido por MuraTORI, Ludovinco Antonio. Della perfetta poesía italiana, ed. de Ada Ruschioni, vol. 1, p. 151; asimismo, Feijoo también alude a lo que él cree que es un comportamiento indigno de un héroe cuando Eneas da muerte a Turno [Eneida, XII, vv. 930-952], pasaje nuevamente ofrecido por MuraTORI, Ludovinco Antonio. Della perfetta poesía italiana, ed. de Ada Ruschioni, vol. 1, p. 150. 
tenía por verdadera; a Manilio, que con la misma buena fe escribió de la astronomía; al mismo Virgilio, como autor de las Geórgicas» (TCU, IV, XIV, § XV, 39, Adición, 8; 1740). Esto debe enfocar ya el debate que Feijoo plantea, que no es el de oponer a Lucano y a Virgilio, sino, más bien, oponer la Farsalia, obra más o menos basada en hechos reales, a la Eneida, obra de gran carga fabulosa.

En segundo lugar, recuerda, valiéndose del testimonio de Horacio, que los primeros poetas prescindieron de fábula. Esto es trascendental, porque la poesía sin fábula, según explica, puede cumplir más eficazmente su cometido último, y de ahí vendrá su prestigio: el que tenían quienes «cantaron instrucciones religiosas, morales y políticas, con que redujeron los hombres de la feroz barbarie en que vivían a una sociedad racional y honesta» (TCU, IV, XIV, § XV, 39, Adición, 9; 1740).

En tercer lugar, razona Feijoo, a causa de que la poesía debe atender a la instrucción, y dado que para la instrucción la ficción es superflua y prescindible -y la prueba evidente de que la poesía ha abandonado su fin primero-, de ahí se desprende su desprestigio: "la poesía en su primera instrucción tenía por objeto deleitar instruyendo: mas con el tiempo se dirigió únicamente al deleite, abandonando la instrucción» (TCU, IV, XIV, § XV, 39, Adición, 9; 1740).

Con ánimo de que veamos la raigambre de esta idea en la poética feijoniana, podemos recordar ahora una afirmación suya de 1726. En aquel entonces, Feijoo se preocupaba por la capacidad didáctica de la poesía sacra y criticaba la poesía religiosa que se estaba escribiendo a la sazón, pues no la veía útil. La poesía religiosa, dice él, no debería tener otro fin que "pintar la hermosura de la virtud, de suerte que enamore; representar la fealdad del vicio, de modo que horrorice; elogiar a Dios y a sus Santos, de forma que el elogio encienda a la imitación", porque «lo grande de la poesía es aquella actividad persuasiva que se mete dentro de la alma y mueve el corazón hacia la parte que quiere el poeta» (TCU, I, XIV, § XII, 49; 1726) ${ }^{53}$.

Así pues, en relación con todo lo anterior, Feijoo cree que la aparición de la fábula puede obstaculizar la instrucción o entrar en contradicción con ella (TCU, IV, XIV, § XV, 39, Adición, 10-13; 1740). Por ello critica Feijoo a Virgilio, quien, según él, poco hace por instruir en su poema. Dice Feijoo de la Eneida:

53. Es importante insistir en el hecho de que Feijoo se muestra partidario de la sátira y la poesía burlesca, siempre que se mantengan dentro de los límites del decoro, justamente por su capacidad para afectar de forma directa sobre las costumbres. Ahora bien, no tolera la hibridación injustificada, y menos cuando se produce en el seno de la poesía religiosa: "Pero aún no he dicho lo peor que hay en las [poesías] cantadas a lo divino; y es que ya que no todas, muchísimas están compuestas al genio burlesco. Con gran discreción por cierto: porque las cosas de Dios son cosas de entremés. ¿Qué concepto darán del inefable Misterio de la Encarnación mil disparates puestos en las bocas de Gil y Pascual? Déjolo aquí, porque me impaciento de considerarlo. Y a quien no le disonare tan indigno abuso por sí mismo, no podré yo convencerle con argumento alguno" (TCU, I, XIV, § XII, 52; 1726). Véase a este respecto LóPez GuIL, Itziar. Poesía religiosa cómico-festiva del bajo barroco español. $1 .^{a}$ ed., Berna: Peter Lang, 2011. 
¿Esta es instrucción o seducción? ¿Es esto disuadir los vicios o autorizarlos? Si los delitos de los hombres son contagiosos para otros con el mal ejemplo; ¿cuántos más inductivos serán esos mismos delitos consagrados (digámoslo así) en las personas de los dioses? Es verdad que Virgilio no hizo en eso más que imitar el mal ejemplo que le habían dado Homero y Hesíodo. Aún por eso Jenófanes abominaba el que estos dos antiguos poetas hubiesen atribuido a las deidades todas las infamias que caben en los hombres. Y Diógenes Laercio y Suidas dicen que Pitágoras vio en el infierno a Homero pendiente de un árbol rodeado de serpientes; y a Hesíodo atado a una columna en pena de las fábulas que habían fingido de los dioses (TCU, IV, XIV, § XV, 39, Adición, 13; 1740).

Como vemos, el reproche estético de Feijoo depende de sus presupuestos éticos y, a su vez, estos derivan de sus convicciones morales y religiosas. Feijoo piensa que la fábula aparece en el poema con el fin único de deleitar, lo que no puede constituir un fin en sí mismo; además, opina que con el objeto de hacer más agradables los escritos se han cometido muchos desvaríos y narrado muchos disparates, de lo cual le parece un ejemplo perfecto el Orlando furioso (TCU, IV, XIV, § XV, 39, Adición, 14; 1740).

Asimismo, nuevamente compartiendo parecer con Muratori, Feijoo considera que nada deleitoso hay en esas fábulas exageradas e inverosímiles que todo lo fían a la actuación de distintos dioses o a diversos hechos sobrenaturales:

No hallo en esas ficciones del fondo de ingenio o altura de numen que algunos pretenden. Muy poco ha, escribió cierto poeta que para fingir unas naves convertidas en ninfas (como Virgilio en la 9 de la Eneida [Eneida, IX, vv. 117-122]) y otros portentos semejantes era menester ingenio más que bumano y erudición casi infinita. ¡Cosa notable! Dijera yo que para encontrar tales quimeras bastaría echarse a dormir; pues el sueño por sí solo las presenta sin socorro alguno del ingenio o de la erudición (TCU, IV, XIV, § XV, 39, Adición, 15; 1740).

De tal forma, Feijoo opina que solo los hombres de poca formación pueden sentirse atraídos por este tipo de fábulas exageradas: "¿Qué ingenio ni qué erudición es menester para esto? Cierto que si esta especie de inventiva es de algún valor, no hay otro en el mundo para pagar el Orlando de Ariosto» (TCU, IV, XIV, § XV, 39, Adición, 15; 1740 $)^{54}$.

No se puede decir más claro, ni pueden extrañarnos, como prueba de todo ello, dos pequeñas notas más. La primera, que como máximo elogio dedicado a Lucano diga Feijoo que Lucano fue "el único poeta que no mintió» (TCU, II, II,

54. Es imposible no recordar ahora la crítica de Cervantes a la ficción exagerada y desmedida, y más todavía cuando Feijoo afirme que ejemplo de esto mismo son "las aventuras de los Paladines, Belianises, Amadises» (TCU, IV, XIV, § XV, 39, Adición, 16; 1740). Debe recordarse, no obstante, que Muratori, que emplea una expresión análoga para referirse a la falta de cultura de quienes escribían o apreciaban tales excesos, si justificaba la irrupción de lo inverosímil en el Orlando por su valor cómico: Muratori, Ludovico Antonio. Della perfetta poesía italiana, ed. de Ada Ruschioni, vol. 1, pp. 147-148. 
$\S$ VIII, 51, Adición 5; 1740); la segunda, que en un poema suyo Feijoo critique a quienes erróneamente

$$
\begin{aligned}
& \text {...han aprendido, } \\
& \text { con grave injuria del arte, } \\
& \text { que consiste el ser poetas } \\
& \text { en huir de las verdades }{ }^{55} \text {. }
\end{aligned}
$$

En resumen, Feijoo se ciñe a defender la utilidad de la poesía y a abogar por que cumpla con los requisitos que la harán provechosa. Por lo tanto, debemos relativizar la oposición entre Virgilio y Lucano, pues, con sus propios argumentos, nada tiene que reprocharle Feijoo a las Geórgicas. El autor del Teatro crítico, por cierto, también consideró a Quintiliano superior a Cicerón, sin que esta otra oposición desencadenase ninguna polémica; y si Feijoo se decantó por Quintiliano fue porque consideró que nos había legado un manual de retórica susceptible de formar nuevos oradores, mientras que Cicerón, precisa Feijoo, solo nos dejó su propia práctica. De esta manera, si Feijoo destacó a Quintiliano, fue también por su inclinación instructiva ${ }^{56}$.

Indudablemente, Feijoo hubo de dolerse de muchos pescozones, porque su discurso en favor del docere fue entendido, a secas, como una acérrima defensa de Lucano respecto de Virgilio, sin parar mientes en todo lo que late bajo tal elección. Así, arrostró docenas de reproches y condescendió a enfangarse en una larga polémica. Entre los reproches, quizá el más célebre sea el que le dirigió Mayans -autor además él mismo de una Vida de Publio Virgilio Marón- quien le indicó por carta que "la comparación de Lucano y Virgilio es odiosa», y, aún más, "delirio", dado que, según Mayans, Lucano es "poeta hinchado" y Virgilio encarna "la perfección total que le hace inimitable» ${ }^{7}$. En lo que a la posterior polémica pública respecta, fue abierta por el jesuita Joaquín de Aguirre, quien publicó en 1742 un combativo escrito sobre el tema dirigido contra Feijoo y titulado El príncipe de los poetas. Virgilio contra las pretensiones de Lucano. Las ramificaciones y repercusiones de la polémica nos llevarían ahora muy lejos ${ }^{58}$, pero debemos hacer

55. López Peláez, Antolín (ed.). Las poesías de Feijoo. 1. a ed., Lugo: G. de Castro, 1899, p. 46.

56. "Así que Cicerón fue orador insigne solo para sí y para todos. La elocuencia de Cicerón fue grande, pero infecunda, que se quedó dentro de un individuo: la de Quintiliano, sobre grande, es utilísima a la especie» (TCU, IV, XIV, § XIV, 32:1730).

57. Mestre, Antonio, "Correspondencia...", p. 176.

58. Sarmiento, como era de esperar, fue uno de los grandes defensores de Feijoo en la polémica, y atacó a quienes reprochaban a la Farsalia no basarse en sucesos imaginarios. Cfr. SARmiento, Martín. Memorias para la Historia de la Poesía y poetas españoles. 1. ${ }^{a}$ ed., Madrid: Joaquín Ibarra, 1775, §113-120, pp. 46-50, luego estudiado por SEBold, Russell P. El rapto de la mente. Poética y poesía dieciochescas. $2 .^{\mathrm{a}}$ ed. [1. ${ }^{\mathrm{a}}$ ed. 1970], Madrid: Ánthropos, p. 136; López Silva, Xosé Antonio. "Feijoo contra los virgilianistas. La polémica sobre Lucano en el XVIII en España», pp. 384-387. Podemos añadir igualmente que José Checa Beltrán atiende al eco que la polémica obtuvo en Francia en 
constar que fue una de las más célebres e influyentes en el mundo literario del momento 5 .

Sea como fuere, todavía Feijoo hubo de volver más tarde sobre el tema, pues no en vano fue uno de sus grandes e ineludibles caballos de batalla, y se vio en la obligación de responder de una vez por todas a la polémica desatada. En 1745, Feijoo insiste en que un poeta no lo es menos si no se vale de la ficción. Repitiendo sus argumentos y citas usuales, explica:

¿Quién no ve que es una cuestión de mero nombre si se debe llamar poesía o no una composición métrica en que no haya ficción alguna? Es verdad que Aristóteles dio por inseparable la fábula de la poesía; pero sin más motivo que querer que fuese pauta para todos los poetas Homero. Y por más que lo haya dicho Aristóteles, el común modo de hablar está y estará siempre en contrario. ¿Por ventura no se cuentan y contaron siempre entre las obras poéticas de Virgilio las Geórgicas, en las cuales no hay ficción alguna? ¿No está colocado en la clase de los poetas Lucrecio, que solo escribió una filosofía que él juzgaba verdadera? ¿Las sátiras de Horacio, Persio y Juvenal, que no contienen otra cosa que corrección de las costumbres viciadas de aquel tiempo, no están anumeradas a las obras poéticas por todo el mundo? ¿Quién hay que no tenga por poéticos los Sacros Himnos de que usa la Iglesia en el Oficio Divino? ¿No llaman todos poemas la María Estuarda de Lope de Vega y la Araucana de Don Alfonso de Ercilla? (CEC, III, V, 7; 1745).

Como puede verse, el recurso al que finalmente acudirá Feijoo para defender a Lucano (CEC, III, V, 8; 1750) es considerarlo como "versificador», dejando a un lado qué sea lo que versificó. Así, "como me concedan que la versificación de este [Lucano] no cede a la de aquel [Virgilio] en valentía, en majestad, en la vivacidad de expresión, en la agudeza de la sentencia, en la harmonía, en el entusiasmo, yo dejaré de muy buena gana que a Lucano censuren el vicio de verídico, reservando a Virgilio y otros la gloria de invencioneros».

Pero lo que a Feijoo de verdad le interesa es volver sobre la función docente del poema. Como sabemos, las ideas de que Feijoo se vale son recurrentes y se aproximan mucho a las ya leídas:

Oponen los de contrario sentir que la poesía no es solo destinada a la instrucción, mas también al deleite de los lectores; y para el deleite, dicen, que es lo principal la fábula. Lo dicen, es verdad; mas se puede negar muy bien que sea verdad lo que

periódicos como las Mémoires de Trevoux y Le Journal Étranger, en CHECA BeLTRÁN, José, "Apuntes sobre la recepción de Feijoo en Francia». En URZAInQui, Inmaculada; Olay VALdés, Rodrigo (eds.). Con la razón y la experiencia. Feijoo 250 años después (en prensa).

59. Tenemos noticia, por ejemplo, tal y como nos recuerda Luis Gil, de que en la Academia de Latinidad de la Corte, José Pastor, a la sazón su secretario, leyó el 16 de diciembre de 1756, entre las conclusiones de los debates anteriores, que "noster Hispanus poeta Lucanus, dignitate canendi, pura Latinitate Virgilum superavit, [nuestro poeta hispano Lucano, merced a la dignidad de su canto, excedió a Virgilio]. GIL, Luis. "Algo sobre el Humanismo español en tiempos de Feijoo". Cuadernos de la Fundación Pastor, 1983, 31, pp. 89-104; la cita en p. 103. 
dicen. Si el verso tiene todos los primores que caben en él, no sé por qué no ha de deleitar tanto diciendo la verdad como diciendo una mentira; y aún más si se dice con más elegancia y hermosura aquella que esta» (CEC, V, XXI, 15; 1760).

El rechazo de la fábula en el poema ya había llevado a Feijoo a criticar a Aristóteles, quien "dio por inseparable la fábula de la poesía; pero sin más motivo que querer que fuese pauta para todos los poetas Homero». (CEC, III, V, 7; 1750); del mismo modo, reivindica Feijoo la importancia de las Geórgicas y aprovecha para atacar a quienes, siguiendo a Aristóteles, han relegado esta obra entre las que el mantuano escribió, como según Feijoo hizo Castelvetro en su edición comentada de la Poética de Aristóteles ${ }^{60}$.

En suma, para Feijoo la historia, versificada con propiedad y guiada por el entusiasmo, puede ser estupenda poesía; y de hecho, a su ver, como la Farsalia prueba, es la mejor poesía. Yendo aún un poco más allá, como la poesía, al gusto de Feijoo, se ha extraviado por ceder a la tentación de la fábula y los poetas ya no cumplen la función docente que les fue propia, entonces los poetas no le parecen tan necesarios como lo fueron en el pasado.

De esta guisa, la ya citada contraposición que Feijoo entabla entre poetas e historiadores le lleva a emprender una cierta crítica del género poético:

¿Qué falta nos harían los poetas? Leí que uno de los más famosos poetas que tuvo la Francia en el siglo pasado (no me acuerdo si era Voiture o Malherbe) solía decir que un buen poeta en una república o reino no era más apreciable ni merecía más estimación que un buen jugador de bolos. Convengo en que este dicho tiene algo de hiperbólico. Pero realmente bien se puede asegurar, que sería mucho más sensible la falta de los historiadores que las de los poetas» (CEC, V, XXI, 24; 1760).

Siguiendo este mismo criterio, consistente en privilegiar la función docente, Feijoo (CEC, V, XXI, 25-26; 1760) insiste en cuán descollante sería que apareciesen los poemas de los primeros poetas -Lino, Orfeo y Museo- y cuánto más todavía si tales poemas careciesen de fábula, lo que los dotaría de un valor añadido a su valía estética; a saber, su dimensión como documento histórico de un periodo remoto del que no tenemos testimonios.

Feijoo defiende que la poesía es un modo más fácil de perdurar y de gozar de éxito crítico que la historia; la convicción que lo lleva a sostener esto es la misma (o casi) que la que le hace preferir la Farsalia a la Eneida: para Feijoo la invención (la ficción) es un recurso pobre, y considera superior el arte que es

60. «No ignoro que el mal acondicionado crítico modenés Luis de Castelvetro, en su comento de la Poética de Aristóteles, absolutamente relegó a las composiciones prosaicas las Geórgicas de Virgilio. Pero no es tanta la autoridad de Castelvetro, que esté alguno obligado a deferir a ella; cuando por otra parte, aunque sirvió algo a la poesía en los preceptos que dio sobre ella, es mucho mayor el deservicio que la hizo, despojándola de una de sus más preciosas alhajas, y tan en alto grado preciosa, que muchos (y cuanto puede decirse) la prefieren a la Eneida» (CEC, V, XXI, 11; 1760). 
capaz de prescindir de ella. Inventando es más fácil encontrar hechos magníficos, bellas reflexiones o hermosas imágenes que desenterrándolas de la realidad; además, Feijoo considera que la dimensión testimonial e histórica de una obra literaria sin ficción es un importante mérito extra ${ }^{61}$ que la hará preferible a una obra enteramente fabulada, dado que las obras de no ficción son más susceptibles de configurar una sociedad "racional y honesta».

Así, Feijoo manifiesta albergar algún recelo en relación con la idoneidad de la poesía, para lo que cita a Jean de Mabillon, quien consideraba inútil para los monjes su estudio (CEC, II, XIII, 35; 1745). Feijoo refiere que el cultivo de las ciencias y de las artes está relacionado con el comportamiento virtuoso de las personas en tanto que vía de perfectibilidad. Sin embargo, encuentra una pequeña salvedad en la poesía, pues no ve tan claro si su escritura induce a la perfección moral, o más bien al desorden:

Es verdad que tanto por los antiguos como por los modernos dados a las letras humanas es menester alguna indulgencia para los profesores de la poesía. O sea, que se inclinan más al ejercicio de este arte los genios amatorios, o que la viveza de la imaginativa, tan necesaria para hacer buenos versos, sea poco conciliable con aquella sosegada madurez que regla las costumbres; no se puede negar que ha habido muchos poetas, especialmente entre los líricos, muy licenciosos, así en los escritos como en las acciones (CEC, IV, 18, 48; 1753).

En todo el discurrir argumentativo de Feijoo (a causa de la introducción de la fábula con fines de puro entretenimiento, la poesía ha dimitido de su función docente original, luego ya no es tan necesaria como lo fue ni tampoco tanto como la historia, y además los poetas suelen ser moralmente disolutos) late, desde luego, el recuerdo de la expulsión de los poetas de la República platónica. Si en el Libro X de La República Platón se mostraba dispuesto a expulsar a los poetas, era justamente porque no colaboraban a hacer mejor el Estado, como los políticos; no hacían descubrimientos geniales para el bien público, como los científicos; y no

61. El propio Feijoo utiliza en alguna ocasión la poesía como documento histórico. Por ejemplo, cuando se ocupa de datar el origen de la brújula (que él llama "aguja náutica»), explica que "por el testimonio del docto Claudio Fauchet en las antigüedades de la lengua y poesía francesa, ni se debe al Gioya Amalfitano haber inventado la aguja náutica ni a Marco Paulo Veneto haber conducido su uso de la China; porque antes de uno y otro se halla memoria de ella en un verso de un poeta francés, llamado Guiot de Provins, que según dicho Fauchet escribió por el año 1200 o algo antes». Los versos a que Feijoo se refieren son los siguientes: "Iccele estiole en se muet / un art font, qui mentir non puet, / par vertu de la marinette, / une pierre laide, et noirette, / ou lefer volentiers se joint.. Y explica que "Marinette es la antigua voz francesa con que se nombraba la aguja magnética o el imán sirviendo a la navegación, como significando inmediatamente piedra del mar» (TCU, IV, XII, § XI, 27, Adición, 1; 1740). 
alcanzaban los logros pedagógicos de los maestros ni las enseñanzas de vida de los filósofos, de modo que, por lo tanto, su actividad era superflua ${ }^{62}$.

Algo resta en Feijoo de ese desprecio por los poetas. Tiene ello su interés, porque no podemos olvidar que él mismo lo era. Ahora bien, no es infrecuente que quienes desarrollaban una labor pública, intelectual o política, sintieran reparos a la hora de dar a conocer sus poemas o a la de confesar que los habían escrito, precisamente por el peso de esta poco prestigiosa imagen convencional del poeta. A este respecto es proverbial el ejemplo de Jovellanos, quien escribió: "[hube de] ocultar cuidadosamente mis versos, conociendo que pues al componerlos había seguido el impulso de los años y las pasiones, no debía hacer una doble injuria a mi profesión con la flaqueza de publicarlos", pues "aunque las obligaciones del hombre en la vida privada son iguales en todos los estados, su pública conducta debe variar según ellos» ${ }^{63}$. Sea como fuere, Feijoo, tras criticar a quienes, por conocer griego ${ }^{64}$, se confesaban en posesión del mayor tesoro cultural existente (lo que irritaba mucho a Feijoo, que no estaba de acuerdo y que además no sabía griego, o que porque no sabía griego no tenía más remedio que no estar de acuerdo), ataca también a quienes solo escriben versos, y abunda en los viejos tópicos que los singularizan:

Estos [los que solo cultivan la poesía] están muy anchos con su pequeña fuente de Hipocrene, que solo los dota de una mínima parte de lo que se llama erudición; esto es, del arte de hacer versos. Y aun dudo que para hacer versos sea muy a propósito ese licor; porque Horacio, que conocía bien el genio de los poetas, no los pinta inclinados a la agua, cuando el príncipe de ellos, Homero, representa dándoles ejemplo muy opuesto a la virtud de la sobriedad (CEC, V, XXI, 6; 1760).

62. Gadamer, Hans Gegorg. "Platón y los poetas». Estudios de filosofía, 1988, 3, pp. 87-108; el dato en p. 89.

63. Jovellanos, Gaspar Melchor de. Obras completas. Escritos sobre literatura, 1. ${ }^{a}$ ed., edición de Elena DE LORENZO ÁlvarEZ, Oviedo: KRK-Instituto n Feijoo de Estudios del Siglo XVIII, 2009, p. 606.

64. En lo concerniente a la utilidad de la poesía griega, recoge Feijoo que «hubo admirables poetas griegos", algunos de los cuales «excedieron a todos los nuestros", pero se pregunta: "¿De qué nos sirven esos mejores poetas? ¿Qué verdades nos enseñan que no nos hagan presentes los autores latinos, poetas y prosistas? ¿Por ventura nos enamoran más de las virtudes o nos inspiran más horror a los vicios?» (CEC, V, XXIII, 11; 1760). Y a causa de la ausencia de utilidad de la literatura griega respecto de la ya conocida, Feijoo considera superfluo el estudio de la lengua helena: "Lo que no se puede negar a los que con perfecta inteligencia del idioma leen los poetas griegos es que siendo esa poesía más enérgica, dulce y armoniosa, como generalmente se admite, será consiguientemente más grata y deliciosa su lectura. Pero sobre que aquí no se trata de la delectabilidad, sino de la utilidad, cualidades diversas así como pertenecen a líneas distintas el bien útil y el delectable, esa mayor delectabilidad no se nos puede transportar acá mediante las traducciones de una lengua a otra, porque la gracia, esplendor y hermosura de un idioma son tan inherentes, especialmente en las composiciones poéticas, al mismo idioma, que cuando se intenta transferirlas a otro diverso casi enteramente pierden su valor» (CEC, V, XXIII, 12; 1760), de modo que, concluye Feijoo, la utilidad de los poemas griegos, que es lo importante, puede percibirse a través de traducciones, y con ello se basta. 
Ahora bien, Feijoo no había perdido la oportunidad de declarar algunos años antes que, pese a todo, no se muestra de la opinión de expulsar a los poetas de la República, como Platón propusiera y Cicerón refrendara. Cree Feijoo que si Cicerón se dirigió con «tanta acerbidad» a los poetas, algo tuvo que ver en ello su propia impericia como poeta $-\mathrm{y}$ saca a colación un verso suyo que fue motivo de mofa: O fortunatam natam me Consule Romam! [Epístola a Ático, II, 3, 4: Oh afortunada Roma, nacida durante mi consulado]- (CEC, IV, 18, 49; 1753). En lo que a Platón respecta, piensa Feijoo que procede su descrédito de la poesía de «la licenciosa petulancia de los cómicos de aquel tiempo" así como de "las insolentes invectivas de Aristófanes» contra Sócrates en Las nubes.

Y es trascendental lo que Feijoo concluye, compendiando su pensamiento poético respecto del prodesse en una sola oración: "Con todo, las intemperancias de los poetas merecen que los corrijan, no que los destierren; porque la poesía, contenida en los justos límites, puede tener sus utilidades" (CEC, IV, XVIII, 50; 1753).

\section{LA NATURALIDAD COMO ESTRATEGIA FRENTE AL BARROQUISMO}

Entusiasmo y versificación son los constitutivos que Feijoo considera que definen la poesía y que además caracterizan perfectamente a quien fuera su poeta favorito, Lucano. Asimismo, Feijoo hostiga con encono a quienes creen que un tercer constitutivo de la poesía debe ser la ficción, de la que descree por completo. A ojos del benedictino, la ficción entorpece el que para él debiera ser cuarto constitutivo de todo poema, es decir, su intencionalidad didáctica. Pero hay todavía un ingrediente más que Feijoo considera indispensable en poesía, como proclamará en repetidas ocasiones e incluso intentará demostrar con su propia práctica poética. Este último constitutivo clave es la naturalidad: «es la naturalidad una perfección, una gracia sin la cual todo es imperfección»(CEC, II, VI, 3; 1745) ${ }^{65}$.

65. Con respecto a la naturalidad como uno de los núcleos esenciales de la propuesta estética feijoniana y una de las aspiraciones principales de su prosa, debe advertirse que se trata de una afirmación relativamente reciente. Vicente de la Fuente, antólogo de Feijoo para la BAE, dedicó todo un capitulillo de su introducción a examinar el estilo de Feijoo, del que afirmó que no le alcanzaba para ser considerado "ni aun como medio hablista"; de la lengua de Feijoo dijo que era todavía "peor, mucho peor" que su estilo (vid. Fuente, Vicente de la (ed.). Obras escogidas del Padre Fray Benito Jerónimo Feijoo. 2. ${ }^{a}$ ed. [ed. original de 1863], Madrid: Atlas, 1952, citas en p. XXVIII). Menéndez Pelayo pensó, como Fuente, que Feijoo fue un "temerario innovador de la lengua" (vid. MenÉnDEz PELAYO, Marcelino. Historia de las ideas estéticas: el siglo XVIII, p. 75), juicio después muy repetido. Esta negativa visión general solo empezaría a corregirse, bien entrado el siglo xx, gracias a trabajos como Montero Díaz, Santiago. "Las ideas estéticas del Padre Feijoo", Delpy. L'Espagne et l'esprit européen: L'œevre de Feijoo (1725-1760), pp. 211-215, o MARAÑón, Gregorio. Las ideas biológicas del Padre Feijoo, pp. 78-87; después de ellos, son fundamentales los trabajos de Di BERNARDO, Elso D. "Acerca de recursos dialécticos, fuentes y procedimientos estilísticos del Padre Feijoo", en VV. AA. Fray Benito Jerónimo Feijoo y Montenegro. Estudios reunidos en conmemoración del II. ${ }^{\circ}$ centenario de su muerte 
Desde su primer tomo del Teatro crítico universal, Feijoo abandera con ímpetu una perseverante reivindicación de la naturalidad. De hecho, confiesa preferir a los escritores franceses de su tiempo en detrimento de los españoles, pero en modo alguno a causa del tan cacareado afrancesamiento, sino debido a que «en aquellos [los franceses] se observa más naturalidad; en estos [los españoles] más afectación. Resplandece en sus obras [las de los franceses] aquella gala nativa, única hermosura con que el estilo hechiza al entendimiento. Son sus escritos como jardines donde las flores espontáneamente nacen; no como lienzos donde estudiosamente se pintan» (TCU, I, XV, § 3, 13; 1726).

Al hilo de estas líneas, recuerda Russell P. Sebold que lo que Feijoo reclama es la vieja pauta de la facilidad difícil ${ }^{66}$. A tal efecto, el símbolo del jardín es claro: lo que Feijoo encarece es aquel estilo que laboriosamente oculta su propia dificultad, lejos de exhibirla, y que hace parecer indeliberados, naturales, sus logros $^{67}$; ejemplifica muy bien esta aspiración Eugenio Gerardo Lobo en los siguientes versos, en que pretende defenderse de su supuesto prosaísmo: "Que escribo versos en prosa / muchos amigos me dicen, / como si el ponerlo fácil / no fuera empeño difícil» ${ }^{68}$.

Allega Russell P. Sebold dos testimonios afines a estos de Feijoo y Lobo: uno de Mayans y otro de Luzán. Mayans se refiere al estilo predominante en el primer cuarto del siglo XVIII, y dice de él que "estudiosamente delira", es decir, todo lo contrario de lo que acabamos de ver que Feijoo reivindica para la mejor literatura. Del mismo modo, Luzán critica el estilo gongorino explicando que se inclina por

(1764-1964). 1. ${ }^{a}$ ed., La Plata: Universidad Nacional de La Plata, 1965, pp. 137-154 (pero, en particular, 142-149); LAPESA, Rafael, "Sobre el estilo de Feijoo" (1966). De la Edad Media a nuestros dias. Estudios de historia literaria. 1. ${ }^{a}$ ed., Madrid: Gredos, 1967, pp. 290-297; DíAZ CASTAÑón, Carmen. "En torno al estilo del Padre Feijoo". En AA. VV., II Simposio sobre el Padre Feijoo y su siglo. Oviedo: Cátedra Feijoo, 1981, t. I, pp. 275-284; el ya aludido de Álvarez DE Miranda, Pedro. "Perfil literario del Padre Feijoo", pp. 126-129, y, recientemente, el de URZAINQUi, Inmaculada. "Estudio introductorio». En URZAINQUI, Inmaculada y SAN José VÁZQUEZ, Eduardo (eds.). Benito Jerónimo Feijoo. Cartas eruditas y curiosas, I. Obras completas, tomo II. 1. ${ }^{a}$ ed., con la colaboración de V. Álvarez Antuña, P. Álvarez de Miranda, S. Cerra Suárez y J. Ordaz Gargallo. Oviedo: Instituto Feijoo de Estudios del Siglo XVIII / Ayuntamiento de Oviedo / KRK, 2014, pp. 97-108.

66. SEBOLD, Russell P. Lírica y poética..., p. 71.

67. Y todo esto porque «la sentencia aguda, el chiste, el donaire, el concepto son adornos precisos de la poesía; pero se han de ver en ella no como que son buscados con estudio, sí como que al poeta se le vienen a la mano. Él ha de seguir su camino según el rumbo propuesto, echando mano solo de aquellas flores que encuentra al paso o que nacen en el mismo camino. Así lo hicieron aquellos grandes maestros, los Virgilios, los Ovidios, los Horacios y cuanto tuvo de ilustre la antigüedad en este arte. Hacer coplas que no son más que unas masas informes de conceptillos es una cosa muy fácil y juntamente muy inútil, porque no hay en ellas ni cabe alguno de los primores altos de la poesía. ¿Qué digo primores altos de la poesía? Ni aun las cualidades que le son de su esencia» (TCU, I, XIV, $\S$ XII, 51: 1726).

68. Álvarez Amo, Francisco Javier. Las "Obras poéticas líricas» de Eugenio Gerardo Lobo (1738). Edición y estudio. 1. ${ }^{\mathrm{a}}$ ed., Tesis Doctoral, Córdoba: Departamento de Literatura Española de la Universidad de Córdoba, 2013, p. 286 
la estética contraria a la que debería, pues «en los poetas la naturalidad y la facilidad aparente es para mí el más hermoso atractivo" ${ }^{69}$.

Esta defensa de la naturalidad se percibe indubitablemente cuando Feijoo se demora en comparar los estilos del historiador y el poeta (TCU, IV, VIII, § V, 13; 1730). El benedictino no está de acuerdo con la clasificación de los géneros en función de los asuntos a que se apliquen; según dicha clasificación, a la historia le corresponde un término medio entre lo sublime y lo humilde. Feijoo disiente y observa que en la historia cabe igualmente la sublimidad, pero una sublimidad que por fuerza no podrá ser equivalente a la que comparece en las obras de los poetas heroicos. De todo ello se desprende que Feijoo no cree que exista un único ideal de sublimidad; de hecho, considera más difícil la sublimidad de la historia que la de la poesía, sencillamente porque el historiador, al tener que circunscribirse a los hechos, cuenta con muchos menos recursos en su paleta, y por lo tanto debe alcanzar efectos próximos a los de la poesía por un camino mucho más estrecho:

No tengo por tan difícil la sublimidad ni en la oratoria ni en la poesía como en la historia; porque en aquellas la frecuencia de tropos y figuras da por sí misma una representación magnífica al estilo; en esta toda la elevación [la] han de costear la viveza de las expresiones, la natural energía de las frases, la profundidad de los conceptos, la agudeza de las sentencias, sin gozar las libertades que gozan el orador y el poeta ya de que el hipérbole desfigure la verdad, ya de que el rapto de la imaginación se malquiste con la integridad del juicio, ya de que la elevación de la pluma dificulte en parte alguna a los ignorantes la inteligencia (TCU, IV, VIII, § V, 13; 1730).

Doblemente interesante es que Feijoo compare fragmentos poéticos e históricos y defienda la elegante concisión de estos en detrimento de aquellos:

Ciertamente, a mí no me parece tan admirable aquella dilatada, hiperbólica y pomposa descripción que hace Claudiano de la avaricia de Rufino, como la breve, enérgica, viva, natural expresión con que Tácito caracteriza en toda su extensión la miseria de Galba: Pecuniae alienae non cupidus, suae parcus, publicae avarus [Historias, I, XLIX: No envidió el dinero ajeno; con el suyo fue austero; con el público, avaro]. Ni la elegante pintura que hizo Ovidio de los triunfos del vicio en la edad del hierro me parece igual a la profundidad de aquella sentencia con que Livio lamentó la última corrupción del pueblo romano: Ad haec tempora perventum est, quibus nec vitia nostra possumus pati, nec remedia [Desde la fundación de Roma, Prefacio: Se llegó a estos tiempos en que no somos capaces de soportar nuestros vicios ni tampoco su remedio] (TCU, IV, VIII, § V, 13; 1730).

Es este otro indicio que apunta al gusto renovador que empieza a despuntar en Feijoo, pues no hace aquí el benedictino sino defender la economía de

69. SEBOLD, Russell P., Lírica y poética..., p. 71. 
recursos, la naturalidad, en suma, y criticar la innecesaria suntuosidad en que puede extraviarse la poesía.

No obstante, esta reivindicación de la naturalidad no puede llevarnos a concluir que Feijoo desprecie la utilización de tropos; todo lo contrario. Como prueban su propia obra poética y, sobremanera, su altísima estimación de la obra de Lucano, Feijoo es partidario de la utilización de un rico lenguaje literario ${ }^{70}$. Lo que no tolera, de nuevo, es la afectación, la acumulación injustificada y oportunista de retruécanos: todo debe estar presidido en el poema por el ideal de naturalidad y por la conciencia clara de simetría y organicidad que la composición poética conforma como un todo:

Aquellos cuyas composiciones se estiman no hacen otra cosa que preparar los conceptillos que les ocurren sobre el asunto; y aunque no tengan entre sí unión de respecto o conducencia a algún designio, los distribuyen en las coplas de modo que todo lo que se llama dicho o concepto, aunque uno vaya para Flandes y otro para Marruecos, se hace que entre en el contexto. Y como cada copla diga algo (así se explican), aunque sea sin moción, espíritu ni fuerza; más es, aunque sea sin orden ni dirección a fin determinado, se dice que es buena composición; siendo así que ni merece nombre de composición, como no merece nombre de edificio un montón de piedras ni el nombre de pintura cualquier agregado de colores (TCU, I, XIV, § XII, 50; 1726).

Se percibe claramente la irritación que en Feijoo despiertan esos poemas trufados de "conceptillos" en que el autor se limita a amontonar retruécanos sin preocuparse de que «uno vaya para Flandes y otro para Marruecos». Tanto debía de molestar esta poesía a Feijoo que él mismo intentó dar muestras en su propia obra poética de los derroteros que él consideraba que le convenía seguir a la lírica de su tiempo, lo que llegó a hacer explícito en algunos de sus poemas. De hecho, Feijoo alcanzó a escribir unas "Liras a una despedida, compuestas en este género de metro, para demostrar que en cuantos usa la poesía cabe naturalidad y ternura ${ }^{71}$. No debe pasarnos inadvertido que sea la lira, introducida en España

70. No hay mejor prueba de esto que su defensa del estilo de Lucano, en el que él no ve "hinchazón» sino «magnificencia del estilo, majestad del numen, grandeza de la locución» (TCU, IV, XIV, $\S \mathrm{XV}, 41 ; 1730)$. Feijoo considera que es el de Lucano paradigma de estilo natural, y que su dicción es briosa, potente, enérgica, inducida por el genio.

71. No conviene perder de vista que no estamos en disposición de afirmar que el título de este poema pueda atribuirse a Feijoo y no sea responsabilidad de alguno de sus editores. Da ello prueba del estado textual aún muy inestable y resbaladizo de la poesía de Feijoo. El poema, por lo demás, pretende rescribir y enmendar la antinaturalidad que halla presente en «Partiéndose a campaña, expresa sentimientos de una despedida", de Gerardo Lobo (véase el texto crítico del poema en Álvarez Amo, Francisco Javier. Las "Obras poéticas líricas” de Eugenio Gerardo Lobo (1738). Edición y estudio, pp. 274-276).

Conviene consignar aquí que la obra en verso de Feijoo ha pasado casi siempre desapercibida, $\mathrm{y}$, de hecho, se halla solo parcialmente recogida en dos ediciones de escasa fiabilidad que cuentan ya más de un siglo (la ya citada de López Peláez, Antolín (ed.), Las poesías de Feijoo, y AreAL, Justo E. (ed.). 
por Garcilaso y consagrada por fray Luis de León, el modelo estrófico que Feijoo elija en concreto para tal propósito. Es cierto que el título del poema es levemente impreciso, porque en realidad Feijoo se vale aquí de una variedad del sexteto-lira y no de la lira propiamente dicha. En cualquier caso, la resonancia de la estrofa, en lo que a su importancia diacrónica se refiere, no cambia en absoluto, pues el sexteto-lira fue la forma métrica de que se valió fray Luis de León nada menos que en sus traducciones de Horacio, y también fue empleada por San Juan de la Cruz, por caso en su "Llama de amor viva».

La lectura del poema feijoniano depara más de una sorpresa, pues resulta evidente que el benedictino busca desprenderse de todo rastro conceptuoso y encarar la escritura del poema de la forma más limpia y delicada posible, sin pretender ocultar los modelos elegidos:

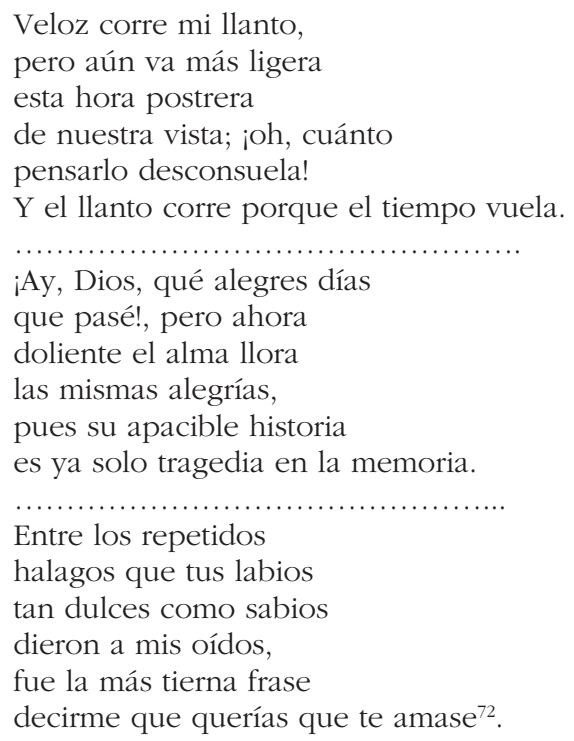

Poesías inéditas del Padre Feijoo. 1. ${ }^{a}$ ed., Tuy: Tipografía Regional, 1901), además de una pequeña colección de variopintas publicaciones. Se hace imprescindible acometer un estudio, en la medida de lo posible, exhaustivo de la poesía de Feijoo que culmine con su edición, lo que tiene por propósito nuestra tesis doctoral. Como prueba el comienzo de esta nota, el análisis de la poesía feijoniana debe ir precedido del correspondiente trabajo ecdótico. Para más detalles al respecto, puede verse Feijoo, Benito Jerónimo, Conversión de un pecador, añadidas unas décimas espirituales, edición, introducción y notas de Rodrigo Olay Valdés, edición digital en PHEBO, 2015, en línea en http://www.uco.es/ investigacion/proyectos/phebo/sites/default/files/feijoo_conversion.pdf.

72. LóPez Peláez, Antolín (ed.). Las poesías de Feijoo, pp. 128-129. 
De esta manera, Feijoo defiende y pretende encarnar el ideal de la poesía española de los Siglos de Oro, y por tanto afirma que «en los asuntos poéticos ninguno hay que las Musas no hayan cantado con alta melodía en la lengua castellana. Garcilaso, Lope de Vega, Góngora, Quevedo, Mendoza, Solís y otros muchos fueron cisnes sin vestirse de plumas extranjeras» (TCU, I, XV, § 5, 22; 1726). Él mismo dice que «majestad, fuerza, elevación son los caracteres con que los sella la nobleza del clima. El siglo pasado [el XVII] vio Manzanares más cisnes en sus orillas que el Meandro en sus ondas» (TCU, IV, XIV, § XV, 44; 1730).

No cabe duda de que contrapuestos a su ideal de naturalidad se encuentran los excesos tardobarrocos de la poesía epigonal que predominaba en vida de Feijoo, y que el benedictino condenó sin ambages:

En los [poetas] españoles, picados de cultura, dio en reinar de algún tiempo a esta parte una afectación pueril de tropos retóricos, por la mayor parte vulgares, una multiplicación de epítetos sinónimos, una colocación violenta de voces pomposas que hacen el estilo no gloriosamente majestuoso, sí asquerosamente entumecido. A que añaden muchos una temeraria introducción de voces, ya latinas, ya francesas, que debieran ser descaminadas como contrabando del idioma o idioma de contrabando en estos reinos. [...] Ciertamente, en España son pocos los que distinguen el estilo sublime del afectado y muchos los que confunden uno con otro (TCU, I, $\mathrm{XV}, \S 3,13 ; 1726)$.

Como se echa de ver, Feijoo afeó con indudable dureza lo que él entiende lamentable estado de la poesía de su tiempo, abanderando de esta manera el comienzo del movimiento poético neoclásico, si lo concebimos como una conciencia de decadencia y una búsqueda de restauración y renovación. Feijoo creía que la excesiva afectación y el uso exagerado de recursos injustificados, al uso más radicalmente barroco, había acabado por desfigurar la poesía española y se ocupó de decirlo desde que comenzó a dar escritos a las prensas: "la poesía en España está mucho más perdida que la música. Son infinitos los que hacen coplas y ninguno es poeta» (TCU, I, XIV, § XII, 45; 1726). Más aún, reiterando su ideal, apreció que

Un poeta excelente es una alhaja rarísima. [...] Si se mira bien, ¿̇dónde se encuentra, entre tantas coplas como salen a la luz, una sola que (dejando otras muchas calidades) sea juntamente natural y sublime, dulce y eficaz, ingeniosa y clara, brillante sin afectación, sonora sin turgencia, armoniosa sin impropiedad, corriente sin tropiezo, delicada sin melindre, valiente sin dureza, hermosa sin afeite, noble sin presunción, conceptuosa sin obscuridad? Casi osaré decir que quien quisiere hallar un poeta que haga versos de este modo le busque en la región donde habita el Fénix (TC I, XIV, § XII, 46; 1726) $)^{73}$.

73. Agudamente, Feijoo se muestra de la opinión de que la gran poesía es un bien escaso y raro, y para dar prueba de ello refiere la siguiente facecia: "El Cardenal de Rets le pidió a Mr. Menage que le diese algunas instrucciones en materia de poesía, las que bastasen para discernir cuáles versos eran 
Y añade, con mayor claridad, si cabe:

Por lo menos en España, según todas las apariencias, hoy no hay que buscarle, porque está la poesía en un estado lastimoso. El que menos mal lo hace (exceptuando uno u otro raro) parece que estudia en cómo lo ha de hacer mal. Todo el cuidado se pone en hinchar el verso con hipérboles irracionales y voces pomposas: conque sale una poesía hidrópica confirmada que da asco y lástima verla. La propiedad y naturalidad, calidades esenciales sin las cuales ni la poesía ni la prosa jamás pueden ser buenas, parece que andan fugitivas de nuestras composiciones. No se acierta con aquel resplandor nativo que hace brillar el concepto; antes los mejores pensamientos se desfiguran con locuciones afectadas, al modo que, cayendo el aliño de una mujer hermosa en manos indiscretas, con ridículos afeites se le estraga la belleza de las facciones (TCU, I, XIV, § XII, 47; 1726).

Como dirá después el propio Feijoo, son «muchos los llamados y pocos los elegidos» (IA, XIV, 1; 1729). Refiriéndose a la poesía sacra, pero de forma que podamos hacer extensivo su juicio a la poesía del momento en general, apunta Feijoo que los poemas a la sazón apenas «consisten en equívocos bajos, metáforas triviales, retruécanos pueriles. Y lo peor es que carecen enteramente de espíritu y moción, que es lo principal o lo único que se debiera buscar. En esta parte han pecado aun los buenos poetas» (TCU, I, XIV, § XII, 48; 1726). Es llamativo, por último, que pese al espacio que Feijoo dedica a evidenciar el mal estado de la poesía española contemporánea, en este punto de su Teatro crítico todavía promete Feijoo algo que por desgracia no llegó a emprender sistemáticamente: referirse por extenso y monográficamente a la poesía de su tiempo: "pero la crisis de la poesía se hará de intento en otro tomo" (TCU, I, XV, § VI, 32; 1726). Sin lugar a dudas, el hecho de que se proponga examinar «la crisis de la poesía» de su tiempo es claro testimonio de la importancia que le concedía.

No debemos perder de vista que con su crítica del barroquismo exacerbado Feijoo se coloca en la parrilla de salida de la estética neoclásica; de hecho, el rechazo feijoniano del barroco tardío acabará convirtiéndose en uno de los lugares comunes del siglo, y muchos otros preceptistas del Dieciocho harán suyo idéntico estandarte. Ignacio de Luzán se refirió a la «no acertada mutación» que el Barroco introdujo $^{74}$. Luis José Velázquez, en sus Orígenes de la poesía castellana (1754), afirma que "después de la entrada de este siglo [el XVIII], en que las letras han tomado entre nosotros otro nuevo semblante, la poesía castellana va volviendo a recobrar su antigua majestad y decoro a pesar de las puerilidades y vicios con que

buenos y cuáles malos, porque muchos iban a mostrarle lo que habían compuesto y le preguntaban qué le parecía de ellos sin que supiese lo que debía responder. Señor, le dijo Mr. Menage, ese es negocio largo y no tiene V. Eminencia tiempo para ello. Pero una breve lección podrá suplir un largo estudio. Cualesquiera versos que le muestren, diga $V$. Eminencia que no valen cosa, que será maravilla que yerre ni una vez en todo un año" (CEC, II, VII, 81; 1745).

74. LuZán, Ignacio de. La poética, edición de Russell P. Sebold, p. 172. 
de nuevo han procurado afearla algunos malos poetas, que pueden considerarse como las últimas reliquias de la ignorancia del siglo pasado ${ }^{75}$. Parecidamente, Juan Andrés escribía en Origen, progreso y estado actual de toda la literatura (1784) que «al oír nombrar el siglo XVII se altera toda la sangre, y desde luego nace en muchos la idea de depravado gusto, de la ignorancia y de la barbarie, teniendo a este siglo en concepto tan vil y despreciable, que se quisiera verle borrado de los fastos de la literatura ${ }^{76}$. Sempere y Guarinos habría de referirse también a estos poetas «de más imaginación que gusto, que introdujeron en España la secta ridícula de los cultos ${ }^{77}$; y Antonio de Campmany no perdió la oportunidad de aludir en su Filosofía de la elocuencia (1777) a la "prodigalidad de paronomasias y equívocos pueriles, de antítesis nominales, de paradojas indefinibles, de hipérboles colosales, de alegorías monstruosas, de sentencias engalanadas, de pensamientos falsos, de enigmas indescifrables, de metáforas forzadas ${ }^{{ }^{78}}$ propia de la poesía barroca.

Los poetas prolongaron esta misma visión de las desproporciones barrocas, y así Cadalso aludió a la "hinchazón y los defectos del mal lenguaje» de los poetas del XVII. Ni Meléndez Valdés perdió la oportunidad de afear el "mal gusto y la hinchazón que en el siglo pasado corrompió nuestra poesía» ni Jovellanos evitó referirse a "estos corrompedores del buen gusto, que arrastr[aron] tras de sí a los demás poetas de aquel tiempo» hasta llegar a "una poesía hinchada escabrosa, llena de artificio y extravagancias ${ }^{79}$. Por último, Leandro Fernández de Moratín también observó que, a causa de la influencia barroca, la poesía de principios de siglo «era toda paranomasias y equívocos, laberintos, ecos, retruécanos y cuanto desacierto es imaginable» ${ }^{80}$. Puede verse con todo esto la importancia cronológica que a Feijoo corresponde en lo concerniente a la crítica de los excesos del Barroco tardío.

75. Citamos por la segunda edición de la obra: VelázQuez, Luis José. Orígenes de la poesía española. 2. ${ }^{a}$ ed. [1. ${ }^{a}$ ed. de 1754], Málaga: Herederos de D. Francisco Martínez de Aguilar, 1797, pp. 63-64.

76. Citamos por LORENZO Álvarez, Elena de. Nuevos mundos poéticos: la poesía filosófica de la Ilustración. 1. ${ }^{a}$ ed., Oviedo: Universidad de Oviedo-Instituto Feijoo de Estudios del Siglo XVIII, 2002, pp. $73-75$

77. Citamos por CheCa Beltrán, José. Pensamiento literario del siglo XVIII español, p. 44.

78. Campmany, Antonio de. Filosofía de la elocuencia. [1. ${ }^{a}$ ed. de 1777], Barcelona: Sierra y Marti, 1826 , p. 16

79. Jovellanos, Gaspar Melchor de. "Carta de Jovellanos a su hermano Francisco de Paula, dedicándole sus poesías» (1780), Obras completas. Tomo I: Obras literarias. 1. a ed., edición crítica, introducción y notas de José Miguel Caso González, Oviedo: Centro de Estudios del Siglo XVIII, 1984, p. 61.

80. Lorenzo Álvarez, Elena de, Nuevos mundos..., p. 76. 


\section{REFLEXIONES FINALES}

Una vez examinados sus escritos al respecto, podemos afirmar que Feijoo entiende la poesía en términos de rapto de la mente, y considera que sus constitutivos esenciales son el entusiasmo y la versificación. Para Feijoo, no hay poesía sin pasión (entusiasmo) ni sin lenguaje distribuido en números regulares (versificación). Con todo, para él es igualmente importante subrayar que la poesía debe prescindir de toda fábula. Esto es así porque Feijoo cree en el poder que la poesía tiene a la hora de influir sobre los hombres y mejorar sus costumbres, para lo que la fábula acaba por ser superflua e inútil. También, atiende el de Casdemiro en especial a la naturalidad del poema.

Se hace fácil a la luz de todo esto comprender el posicionamiento de Feijoo en el célebre Pleito de Lucano. Feijoo no abandera una carpetovetónica reivindicación a ultranza de la literatura patria: sencillamente, muestra su preferencia por la Farsalia de Lucano frente a la Eneida de Virgilio, porque halla en esta última ciertos defectos que no alcanza a compensar el indudable magisterio poético -afirmado por el propio Feijoo- del mantuano. Feijoo encuentra en la Farsalia un lenguaje poderoso y encendido por el numen y una decidida ausencia de contenidos fabulados; en la Eneida, una dicción excesivamente dulce y armoniosa, que llega a hacérsele monocorde, y, sobre todo, una omnipresente sobreabundancia sucesos inverosímiles y mágicos debidos a la acción constante de falsas deidades obstinadas además en comportarse de forma censurable, gobernadas por pasiones humanas. En la Farsalia halla Feijoo la verdad de la historia y su claridad pedagógica; en la Eneida, los desmanes de la fábula y la ausencia de modelos virtuosos. Conviene insistir en que Feijoo en modo alguno deploró a Virgilio, como ha solido repetirse; sin cambiar un ápice su argumentación, pudo haber defendido las Geórgicas respecto de la Eneida (didactismo y no ficción frente a entretenimiento y fantasía), pues lo que en esencia dirime el Pleito de Lucano no es la preferencia feijoniana por el épico cordobés, sino su defensa del prodesse en poesía.

Desilusionado ante la proliferación de poemas que no encarnan lo que él piensa que debe ser la poesía, Feijoo proclama su preferencia por la historia como género que, cree él, ha venido a llenar el espacio que los poetas han dejado vacío. El género histórico es más susceptible de verse orientado a la formación de sus lectores y goza además de otra clara virtud: el registro lingüístico que lo conforma no puede acudir al recargamiento de figuras que sí es tolerable en poesía y por lo tanto es propio de su estilo y de su ideal de sublimidad un mayor despojamiento. Sin embargo, Feijoo no llega a entonar un completo rechazo de la poesía ni de los poetas, pues considera que todavía es tiempo de que ambos vuelvan por sus fueros.

La preferencia feijoniana por la historia enlaza con otro de los constitutivos fundamentales de la poesía a los que antes nos referimos: la naturalidad. Feijoo reivindica a lo largo de su obra en prosa, y pretende encarnar incluso con algunos ejemplos de su obra en verso, el ideal clásico de la difícil facilidad, de la elaborada 
espontaneidad como máximo logro del poeta y de la limpieza como consecuencia del labor limae. Feijoo se muestra cansado de aquella poesía contemporánea que no pretende más que acumular retruécanos y «conceptillos» y que se fía continuamente a la superposición de figuras sin manifestar ninguna idea de conjunto, porque una va "para Flandes» y otra "para Marruecos». En conclusión, Feijoo repudia los procedimientos poéticos tardobarrocos más recargados y a ellos opone el ideal de naturalidad y elegancia de la poesía del siglo de Augusto. 